\title{
Exploring the role of bedrock representation on plant transpiration response during dry periods at four forested sites in Europe
}

\author{
César Dionisio Jiménez-Rodríguez ${ }^{1}$, Mauro Sulis ${ }^{1}$, and Stanislaus Schymanski ${ }^{1}$ \\ ${ }^{1}$ Environmental Research and Innovation (ERIN) Department, Luxembourg Institute of Science and Technology (LIST), \\ Belvaux, L-4422, Luxembourg.
}

Correspondence: César Dionisio Jiménez-Rodríguez (cesar.jimenez@list.lu)

\begin{abstract}
Forest transpiration is controlled by the atmospheric water demand, potentially constrained by soil moisture availability, and regulated by plant physiological properties. During summer periods, soil moisture availability at sites with thin soils can be limited, forcing the plants to access moisture stored in the weathered bedrock. Land surface models (LSMs) have considerably evolved in the description of the physical processes related to vegetation water use but the effects of bedrock position and water uptake from fractured bedrock has not received much attention. In this study, the Community Land Model version 5.0 (CLM 5) is implemented at four forested sites with relatively shallow bedrock and located across an environmental gradient in Europe. Three different bedrock configurations (i.e., default, deeper, and fractured) are applied to evaluate if the omission of water uptake from weathered bedrock could explain some model deficiencies with respect to the simulation of seasonal transpiration patterns. Sap flow measurements are used to benchmark the response of these three bedrock configurations. It was found that the simulated transpiration response of the default model configuration is strongly limited by soil moisture availability at sites with extended dry seasons. Under these climate conditions, the implementation of an alternative (i.e., deeper and fractured) bedrock configuration resulted in a better agreement between modeled and measured transpiration. At the site with a continental climate, the default model configuration accurately reproduced the magnitude and temporal patterns of the measured transpiration. The implementation of the alternative bedrock configurations at this site provided more realistic water potentials in plant tissues but negatively affects the modeled transpiration during the summer period. Finally, all three bedrock configurations did not show differences in terms of water potentials, fluxes, and performances on the more northern and colder site exhibiting a transition between oceanic and continental climate. Model performances at this site are low, with a clear overestimation of transpiration compared to sap flow data. The results of this study call for increased efforts into better representing lithological controls on plant water uptake in LSMs.
\end{abstract}

Keywords: sap flow, transpiration, weathered bedrock, soil texture, plant hydraulic traits. 
https://doi.org/10.5194/bg-2021-311

Preprint. Discussion started: 28 January 2022

(c) Author(s) 2022. CC BY 4.0 License.

\section{(c) (i)}

\section{Introduction}

Bedrock structure and composition influence the ecosystem productivity (Hahm et al., 2014; Jiang et al., 2020) through its effect on plant nutrient and water uptake (Ding et al., 2021). Physical and chemical weathering processes allow the formation of cracks in the bedrock (Pope, 2015), increasing the presence of water reservoirs that are commonly neglected in ecological analyses at sites characterized by thin soils and seasonal droughts (Sternberg et al., 1996). These reservoirs are highly dynamic, storing water from winter precipitation (Vrettas and Fung, 2017) and sometimes holding even more moisture than the overlying soil (Rempe and Dietrich, 2018). The thickness of the weathered bedrock varies according to rock type and climatic conditions; some European sites with gneiss, granite, and flysch rock types have mean thicknesses of $7.0 \mathrm{~m}, 4.6 \mathrm{~m}$, and $3.4 \mathrm{~m}$, respectively (Šamonil et al., 2020). Plants growing in seasonally dry environments rely on deep water reservoirs often available within the weathered bedrock (Barbeta et al., 2015; Ding et al., 2021; Sternberg et al., 1996). As an example, vegetation growing in karst systems are able to access water stored in the fractured bedrock thanks to the presence of sediments and organic matter within the cracks of the first $2 \mathrm{~m}$ of soil that increase the water holding capacity of the karst formation (Phillips et al., 2019; Querejeta et al., 2007; Swaffer et al., 2014). However, due to the limited field data, detailed knowledge about the structure of weathered bedrock and its effect on the overlying vegetation remains poorly understood.

Plant transpiration is driven by atmospheric water demand and controlled by stomata, where water diffuses away from leaves along the same pathway as $\mathrm{CO}_{2}$ enters the leaves before it is fixed through the photosynthesis. Water transpired by leaves needs to be replenished by root water uptake and suction-driven transport from roots to leaves. The plant hydraulic system enabling this transport is vulnerable to embolism under strong suction (e.g. low soil water potential), therefore plants reduce stomatal conductance and transpiration under such conditions (Kirkham, 2014; Sperry et al., 1998, 2002). Trees developed a number of strategies that enhance and guarantee the access to different water sources depending on the environmental conditions. Their root system can extend horizontally over large areas (e.g, Abies sp., Meterosideros sp.) or vertically into the ground (e.g, Quercus sp., Pinus sp.) reaching depths of more than $20 \mathrm{~m}$ (Pallardy, 2008). During prolonged dry periods, some tree species use these extended root systems to access deep groundwater reservoirs (Barbeta et al., 2015; Zhang et al., 2018), redistribute water in superficial soil layers through hydraulic lift (Alagele et al., 2021; Bayala and Prieto, 2020), and/or source water from the weathered and fractured bedrock (Ding et al., 2021; Querejeta et al., 2007; Sternberg et al., 1996; Swaffer et al., 2014). This latter water pool (i.e., moisture extracted by roots from the weathered bedrock) is poorly quantified at the global scale and especially for forested ecosystems that are widespread on hillslopes with thin soils (Jiang et al., 2020; Schwinning, 2010).

Land surface models (LSMs) have evolved considerably over the last decades and have been established as useful tools to understand ecosystem responses to water stress conditions and heat waves (Fisher and Koven, 2020). The representation of subsurface hydrological processes and groundwater flow varies quite strongly between LSMs. For instance, the Joint UK Land Environment Simulator (JULES) LSM has a $10 \mathrm{~m}$ soil column with 28 soil layers (with 14 layers distributed over the first $3 \mathrm{~m}$ of soil). This soil column can be shallower depending on the site conditions, where the bedrock is considered only for temperature 
https://doi.org/10.5194/bg-2021-311

Preprint. Discussion started: 28 January 2022

(c) Author(s) 2022. CC BY 4.0 License.

\section{(c) (i)}

exchange and not for groundwater storage (Chadburn et al., 2015). NOAH LSM includes an unconfined aquifer beneath a soil column of $2 \mathrm{~m}$ depth allowing the soil column to drain freely (Niu et al., 2011). The Organising Carbon and Hydrology In Dynamic Ecosystems (ORCHIDEE) LSM has a total soil depth of $2 \mathrm{~m}$, allowing multiple soil layer discretizations (Campoy et al., 2013), with the bedrock defining a discontinuity in the soil zone processes (Sun et al., 2021). Finally, the Community Land Model version 5.0 (CLM 5) implements a spatially distributed soil thickness (Swenson and Lawrence, 2015) within a range of $0.4 \mathrm{~m}$ to $8.5 \mathrm{~m}$ depth, derived from a spatially explicit soil thickness data product (Pelletier et al., 2016). Water stored in the unsaturated zone is under negative pressure and considered as the only source of plant water by the model. Depending on the soil water balance, a saturated zone builds up on top of the bedrock but this is a temporal water storage from where any water excess moves out as drainage. Overall, LSMs are based on the common assumption that soil water is the main water source for the vegetation, and the deep drainage is used only for river and/or wetland flow routing and hence neglected as a potential source of water. This conceptualization results in a critically low storage capacity for plant available water at sites characterized by thin soil and prolonged dry periods. Furthermore, due to the lack of detailed field observations for accurately determining the depth-to-bedrock (DTB), this conceptualization leads to a large uncertainty in applying LSMs at such sites (Shangguan et al., 2017).

Recent field evidence documents vegetation dependency on rock moisture during dry periods or extended droughts (Carrière et al., 2020; Klos et al., 2018; Hahm et al., 2020; Jiang et al., 2020; Nardini et al., 2021; Qi et al., 2018; Rempe and Dietrich, 2018), and the dependence of maximum rooting depths on the in-situ hydrological regulation (Fan et al., 2017). However, consideration of rock moisture in current models is scarce and the few examples are linked to model rock weathering processes (Cipolla et al., 2021) leaving aside its role for root water uptake and plant transpiration (Fan et al., 2019). From a pragmatic modelling perspective, the inclusion of this additional source of water could be achieved either by implementing a bottomless soil column allowing the exponential root profile to access deep soil water (de Rosnay and Polcher, 1998) or deepening the DTB and/or altering the soil composition for the bedrock layers. This latter approach emphasizes the key role played by soil texture in regulating the response of root and plant hydraulics to soil drying (Cai et al., 2021; Carminati and Javaux, 2020) as well as the effect of uncertainty in determining the DTB (Brunke et al., 2016).

The objective of this work is to evaluate the impact of different bedrock conceptualizations on the simulation of plant transpiration response using CLM 5. The underlying hypothesis of the work is that the omission of plant available water stored in the weathered bedrock could explain some of the model deficiencies in reproducing seasonal transpiration patterns. It is expected that during summer the vegetation is fully developed, extracting soil water at maximum rate and relying on deeper soil water pools soil water pools during extended dry periods. To test this hypothesis, CLM 5 is implemented at four forested sites located across an environmental gradient in Europe using three different bedrock configurations, (i) the model default, (ii) a deeper location of the impermeable layer, and (iii) a weathered bedrock overlying the impermeable bedrock. The simulated plant transpiration of the three model configurations is compared to the up-scaled transpiration signal measured by sap flow sensors at the selected study sites. Finally, the plant physiological implications of using different bedrock configurations are assessed by examining the plant vulnerability curves of the xylem and leaf segments of the simulated plants. 
https://doi.org/10.5194/bg-2021-311

Preprint. Discussion started: 28 January 2022

(c) Author(s) 2022. CC BY 4.0 License.

(c) (i)

\section{Study Sites}

Figure 1a illustrates the spatial distribution of DTB across a domain covering a large part of the European continent; $43 \%$ of the area with DTB between $0 \mathrm{~m}$ and $2 \mathrm{~m}, 40 \%$ between $2 \mathrm{~m}$ and $40 \mathrm{~m}$, and $17 \%$ with depths larger than $40 \mathrm{~m}$ (Pelletier et al., 2016). This geological pattern is overlaid by three main climatic zones according to the Köppen-Geiger climate classification: (i) warm temperate climate with dry summers (Cs) surrounding the Mediterranean sea, (ii) warm temperate fully humid climate (Cf) located in the central part of Europe, and (iii) a snow fully humid climate (Df) covering Eastern Europe and the Scandinavian Peninsula (Beck et al., 2018). The four study sites were selected from the SAPFLUXNET data set (Poyatos et al., 2021) in order to sample the dominant geological and climate settings of the European continent (Table 1). These sites have DTB no larger than $1.5 \mathrm{~m}$ covering the shallow soils in mountain ranges (ES-Alt), foothills (FR-Pue, FR-Hes), and lowlands (RU-Fyo) and are distributed across an environmental gradient (of mean annual precipitation: $400-900 \mathrm{~mm} \mathrm{yr}^{-1}$, and air temperature: 4.7-13. $8^{\circ} \mathrm{C}$ ) where the FR-Pue and ES-Alt sites exemplify the Cs climate class of the Mediterranean basin, FR-Hes the Cf class of Central Europe, and RU-Fyo the Df class of Eastern Europe.

\subsection{Spain, Alto Tajo [ES-Alt]}

This research site is located in the Alto Tajo Natural Park $\left(40.8044^{\circ} \mathrm{N}-2.2328^{\circ} \mathrm{W}\right)$. The main soil types are classified as calcaric cambisols, mollicleptosols, and rendzic leptosols (Zapico et al., 2017). These soils are formed from Cretaceous carbonate rocks settled on top of sandy sediments (Carcavilla et al., 2008), with a poor soil development (Granda et al., 2012), and a thickness ranging from $25 \mathrm{~cm}$ up to $1.0 \mathrm{~m}$ depth (Martín-Moreno et al., 2014). The climate is classified as continental Mediterranean, with a summer precipitation characterized by high-intensity rainstorms (Martín-Moreno et al., 2014), and snow fall during winter (Acuña Míguez et al., 2020). The site registered a mean annual temperature and precipitation of $11.7^{\circ} \mathrm{C}$ and $567 \mathrm{~mm} \mathrm{yr}^{-1}$, respectively (Poyatos et al., 2016). The vegetation is characterized by four types of forest communities dominated by Juniperus thurifera L., Pinus nigra J.F. Arnold ssp. salzmannii (Dunal) Franco, Quercus faginea Lam., and Quercus ilex ssp. ballota (Desf) Samp. (Forner et al., 2014). The plant functional type (PFT) for this site is broadleaf evergreen tree (BET).

\subsection{France, Puechabon [FR-Pue]}

The Puechabon research site $\left(43.4417^{\circ} \mathrm{N}-3.5944^{\circ} \mathrm{E}\right)$ is characterized by soil limitations linked to the hard Jurassic limestone formation beneath it (Cabon et al., 2018). The soil does not have a clear differentiation of horizons (Shahin et al., 2013), with a silty clay loam soil texture (Reichstein et al., 2002). This location has a Mediterranean climate with a mean annual precipitation of $1023.0 \mathrm{~mm} \mathrm{yr}^{-1}$ and a mean annual temperature of $13.8^{\circ} \mathrm{C}$ (Poyatos et al., 2021). The forest canopy is dominated by Quercus ilex, while the understorey is sparse and dominated by shrubs such as Buxus sempervirens L., Phyllirea latifolia L., Pistacia 
https://doi.org/10.5194/bg-2021-311

Preprint. Discussion started: 28 January 2022

(c) Author(s) 2022. CC BY 4.0 License.

(c) (i)

terebinthus L. and Juniperus oxycedrus L. (Allard et al., 2008). Similarly to ES-Alt, the PFT is classified as BET, due to the dominance of Quercus ilex.

\subsection{France, Hesse [FR-Hes]}

The Hesse experimental site $\left(48.6742^{\circ} \mathrm{N}-7.0647^{\circ} \mathrm{E}\right)$ is located on top of a sandstone formation, with a gentle southern slope (Le Goff and Ottorini, 2001), and a soil classified as Luvisol/stagnic luvisol with a maximum soil depth of $145 \mathrm{~cm}$ depth (Granier et al., 2007). It has a semi-continental climate with a mean annual temperature of $10.0^{\circ} \mathrm{C}$ and a mean annual precipitation of $1003 \mathrm{~mm} \mathrm{yr}^{-1}$ (Poyatos et al., 2021). The vegetation is dominated by Fagus sylvatica L. with $90 \%$ of the trees, with the remaining $10 \%$ represented by Carpinus betulus L., Betula pendula Roth, Quercus petraea (Matt.) Liebl., Larix decidua Mill., Prunus avium L., and Fraxinus excelsior L. (Granier et al., 2000). Understorey vegetation is sparse as a consequence of a closed canopy and the mineral soil is covered by a mull type humus (Daniel Epron et al., 2004; Le Goff and Ottorini, 2001). The dominant PFT is classified as broadleaf deciduous tree (BDT).

\subsection{Russia, Fyodorovskoye [RU-Fyo]}

The Fyodorovskoye experimental site $\left(56.4615^{\circ} \mathrm{N}-32.9221^{\circ} \mathrm{E}\right)$ is located in the Central Forest Reserve in the Tver region, Russia. The soils are classified as Eutric Podzoluvisol and Gleyic Podzolavisol and characterized by their poor drainage, poor soil aeration, and bog growth on the surface (Vygodskaya et al., 2002). The site lithology describes a previous vast periglacial lake at $8 \mathrm{~m}$ depth, above which the peatland started forming (Novenko and Zuganova, 2010) and still present. The climate is a transition between European Oceanic to continental climate being classified as moderately continental (Schulze et al., 2002) with a mean annual precipitation of $719.7 \mathrm{~mm} \mathrm{yr}^{-1}$ and a mean annual temperature of $4.7^{\circ} \mathrm{C}$ (Poyatos et al., 2021). The forest stand is dominated by the tree species Picea abies (L.) Karst (Norway spruce), Betula pubescens L. (Birch) and some Pinus sylvestris L. (Scots pine) (Kurbatova et al., 2013; van der Laan et al., 2014). The dominance of coniferous trees at this site determines the needleleaf evergreen tree (NET) PFT classification.

\section{Methodology}

\subsection{Model Implementation}

CLM 5 (Lawrence et al., 2019) was implemented at each experimental site using point-scale setups. Hourly atmospheric forcings (precipitation, wind speed, air temperature, relative humidity, atmospheric pressure, and incoming shortwave radiation) were retrieved from the SAPFLUXNET data set. Incoming longwave radiation was determined based on air temperature and ac- 
https://doi.org/10.5194/bg-2021-311

Preprint. Discussion started: 28 January 2022

(c) Author(s) 2022. CC BY 4.0 License.

(c) (i)

tual air vapor pressure according to An et al. (2017), while missing variables (i.e, atmospheric pressure) and missing data were filled using COSMO-REA6 reanalysis product (Bollmeyer et al., 2015). The plant functional types (PFTs) broadleaf evergreen tree (BET), broadleaf deciduous tree (BDT), and needleleaf evergreen tree (NET) describe the vegetation cover of the different experimental sites. CLM 5 implements a default plant physiological parameterization based on previous published data for the root distribution (Jackson et al., 1996) and plant hydraulics (Kattge et al., 2011; Kennedy et al., 2019). Site-specific monthly leaf area index (LAI) values were computed based on the $1 \mathrm{~km}$ Global Land Surface Satellite (GLASS) product provided every 8 days (Liang et al., 2013, 2014). In order to account for inter-annual variability in the plant phenological development, yearly model runs were performed where the LAI information was updated at the start of each run. Default soil texture profiles (Bonan et al., 2002) and default depth to bedrock (Pelletier et al., 2016) were used at each site; see Table 1 for summary information. The simulations were carried out over different time periods (i.e, 2012-2014 at ES-Alt, 2001-2011 at FR-Pue, 2001-2005 at FR-Hes, and 2001-2003 at RU-Fyo) covering some of most extreme drought events in Europe (e.g., 2003 and 2006). Finally, soil moisture and soil temperature were initialized by performing multi-year spin-up runs, with CLM 5 repeatedly reinitialized until dynamic equilibrium condition was reached.

\subsection{Bedrock configurations}

In CLM 5 the plant access to soil water is controlled by the PFT-specific root distribution parameter $(\beta)$ based on the formulation proposed by Jackson et al. (1996). This parameterization results in an exponentially decreasing root profile with soil depth, which is truncated by the position of the bedrock. The water acquisition by the plants is constrained by the effective soil depth as set by the DTB static parameter, which implies that all soil layers beneath DTB are impermeable and without water holding capacity; see schematic of Fig. 1b for a graphical illustration of the intersection between root distribution and DTB as conceptualized in CLM 5.

Three model configurations were constructed in order to mimic the influence of bedrock representation (and omitted subsurface water storage) on the modeled transpiration during dry periods. The first configuration (default model configuration: DMC) uses the default soil texture and DTB parameters for each location. The second configuration (deeper bedrock configuration: DBC) shifts the bedrock depth of all sites down by $1.5 \mathrm{~m}$, while keeping the same default soil texture classification. The third configuration (fractured bedrock configuration: FBC) uses the extended DTB of the second configuration, but parameterizes the soil texture of the layers laying in between the original and the new DTB as $90 \%$ sand and $10 \%$ clay (Table 1). This modification aims to mimic the hydrological behaviour of a fractured bedrock. 
https://doi.org/10.5194/bg-2021-311

Preprint. Discussion started: 28 January 2022

(c) Author(s) 2022. CC BY 4.0 License.

(c) (i)

\subsection{Data Analysis}

\subsubsection{Reference evaporation and observed transpiration}

To assess the effect of water stress on transpiration rates, the unstressed reference crop evaporation $\left(E_{\mathrm{o}}\right)$ was calculated following Allen et al. (1998) using Equation 1. This equation assumes a reference crop of $0.12 \mathrm{~m}$ height characterized by a surface resistance of $70 \mathrm{~s} \mathrm{~m}^{-1}$ and an albedo of 0.23 . This equation requires wind speed $(u)$ in $\mathrm{m} \mathrm{s}^{-1}$, net radiation $\left(R_{\mathrm{n}}\right)$ and ground heat flux $(G)$ both in $\mathrm{MJ} \mathrm{m}^{-2} \mathrm{~d}^{-1}$, air temperature $(T)$ in ${ }^{\circ} \mathrm{C}$, the actual and saturated vapour pressures $\left(e_{\mathrm{a}}\right.$ and $e_{\mathrm{s}}$, respectively) in $\mathrm{kPa}$. $G$ was extracted from the modeled results of the DMC for each site. The slope of the saturation vapour pressure curve at air temperature $\left(\Delta, \mathrm{kPa}^{\circ} \mathrm{C}\right)$ was computed using equation 2 . The psychrometric constant $(\gamma)$ was estimated with equation 3, where $\lambda$ is the latent heat of vaporization $\left(2.45 \mathrm{MJ} \mathrm{kg}^{-1}\right), c_{\mathrm{p}}$ is the specific heat at constant pressure $\left(1.013 \times 10^{-3}\right.$ $\left.\mathrm{MJ} \mathrm{kg}^{-1}{ }^{\circ} \mathrm{C}^{-1}\right), p$ is the atmospheric pressure $(\mathrm{kPa})$, and $\epsilon$ is the molecular weight ratio of water vapour and dry air $(0.622)$.

$E_{\mathrm{o}}=\frac{0.408 \cdot \Delta \cdot\left(R_{\mathrm{n}}-G\right)+\gamma \frac{900}{T+273} \cdot u \cdot\left(e_{\mathrm{s}}-e_{\mathrm{a}}\right)}{\Delta+\gamma \cdot(1+0.34 u)}$

180

$\Delta=\frac{4098 \cdot\left(0.6108 \cdot \exp \left(\frac{17.27 . T}{T+237.3}\right)\right)}{(T+237.3)^{2}}$

$\gamma=\frac{c_{\mathrm{p}} p}{\epsilon \lambda}$

Hourly and sub-hourly sap flux of individual trees $\left(Q_{\text {tree }}\right) \mathrm{in} \mathrm{cm}^{3} \mathrm{hr}^{-1}$ was retrieved from the SAPFLUXNET data set (Poyatos et al., 2021) for each experimental site and aggregated to daily fluxes $\left(\mathrm{m}^{3} \mathrm{~d}^{-1}\right)$. Daily transpiration fluxes were upscaled to stand transpiration $\left(E_{\mathrm{T}}\right)$ in $\mathrm{mm} \mathrm{d}^{-1}$ using equation 4 and following the recommendations by Nelson et al. (2020). This equation requires the transpiration flux $\left(Q_{\text {tree }}\right)$ in $\mathrm{m}^{3} \mathrm{~d}^{-1}$ tree $^{-1}$, the tree basal area $\left(\Upsilon_{\text {tree }}\right)$ in $\mathrm{m}^{2}$ tree ${ }^{-1}$, the stand basal area $\left(\Upsilon_{\text {stand }}\right)$ in $\mathrm{m}^{2} \mathrm{~m}^{-2}$, and the number of measured trees $(n)$. All information required in Equation 4 was extracted from the SAPFLUXNET data set for each site.

$E_{\mathrm{T}}=\frac{\Upsilon_{\text {stand }}}{n \cdot 10^{3}} \cdot \sum_{\text {tree }=1}^{n} \frac{Q_{\text {tree }}}{\Upsilon_{\text {tree }}}$

At each site the daily standard deviation of transpiration rates $\left(E_{\mathrm{T}-\sigma}\right)$ provides an indication of the different response of individual trees (including different species) to the environmental drivers. Table 1 shows the maximum $\left(\sigma_{\max }\right)$, median $\left(\sigma_{\text {median }}\right)$, 
and mean $\left(\sigma_{\text {mean }}\right)$ values of $E_{\mathrm{T}-\sigma}$ for the selected time periods. FR-Hes is the site where the sampled trees have the largest variability in the transpiration response $\left(\sigma_{\text {mean }}: 0.71 \mathrm{~mm} \mathrm{~d}^{-1}, \sigma_{\text {median }}: 0.62 \mathrm{~mm} \mathrm{~d}^{-1}\right)$, while the other three sites show similar median and mean values close to $\sim 0.3 \mathrm{~mm} \mathrm{~d}^{-1}$. FR-Pue and FR-Hes display $\sigma_{\max }$ values $\left(3.53 \mathrm{~mm} \mathrm{~d}^{-1}\right.$ and $4.3 \mathrm{~mm} \mathrm{~d}^{-1}$, respectively) that are three-fold larger than those in ES-Alt and RU-Fyo $\left(\sigma_{\max }: \sim 1.0 \mathrm{~mm} \mathrm{~d}^{-1}\right)$. These large $\sigma_{\max }$ suggest the strong intra-specific variability of transpiration response to the meteorological conditions for forest stands dominated by a single tree species. Sites such as ES-Alt and RU-Fyo characterized by mixed forest stands experience a more homogeneous transpiration response among the sampled trees.

\subsubsection{Index of Agreement}

The daily stand transpiration $\left(E_{\mathrm{T}}\right)$ in $\mathrm{mm} \mathrm{d}^{-1}$ was compared to the simulated transpiration of the three model configurations (see section 3.2). The relative comparison of the three bedrock representations was carried out by applying a symmetric index of agreement $(\Gamma)$ proposed by Duveiller et al. (2016). The index is calculated using Equation 5 and is based on the product between the Pearson correlation coefficient $(r)$ and an $\alpha$ coefficient, which scales $r$ as a measure of agreement. When $r$ is negative, $\alpha$ becomes zero under the consideration that a negative correlation does not show agreement when comparing against a benchmark. Consequently, $r$ is a measure of the linear agreement/dependence reflecting how well the measured and simulated transpiration time series agree in terms of their temporal deviations with respect to their mean responses, and the term $\alpha$ represents any bias (additive/multiplicative) between the two data sets and ranges between 1 (no bias, perfect agreement) and 0 (full bias, no agreement).

$\Gamma=\alpha \cdot r ;$ where $\alpha= \begin{cases}0 & , \text { if } r \text { is } \leqslant 0 \\ \frac{2}{\frac{\sigma_{\mathrm{X}}}{\sigma_{\mathrm{Y}}}+\frac{\sigma_{\mathrm{Y}}}{\sigma_{\mathrm{X}}}+\frac{(\bar{X}-\bar{Y})^{2}}{\sigma_{\mathrm{X}} \cdot \sigma_{\mathrm{Y}}}} & , \text { otherwise }\end{cases}$

\subsubsection{Plant Vulnerability Curve}

210 The physiological implication of the plant response based on the three bedrock configurations is analyzed using the vulnerability curve of the plant hydraulic system as implemented in CLM 5 (Kennedy et al., 2019). Equation 6 expresses the plant segment hydraulic conductivity $\left(k, \mathrm{~s}^{-1}\right)$ as a function of tissue water potential $(\psi, \mathrm{MPa})$ and contains three parameters: the water potential at $50 \%$ loss of conductivity $\left(\psi_{\mathrm{p} 50}\right)$ in MPa, the maximum conductivity $\left(k_{\max }\right)$ of the plant segment in s $\mathrm{s}^{-1}$, and 
https://doi.org/10.5194/bg-2021-311

Preprint. Discussion started: 28 January 2022

(c) Author(s) 2022. CC BY 4.0 License.

(c) (i)

Discussions

the non-dimensional sigmoidal shape-fitting parameter of the curve $\left(c_{\mathrm{k}}\right)$. These parameters are defined at the PFT-level and reported in Table 1 for the different selected sites.

$k=k_{\max } \cdot 2^{-\left(\frac{\psi}{\psi_{\mathrm{p} 50}}\right)^{c_{\mathrm{k}}}}$

The loss of hydraulic conductivity in a plant segment $\left(\Xi_{\mathrm{PLC}}\right)$ due to low tissue water potential can also be expressed as the percent of conductivity $(\Xi)$ (Equation 7), with $0 \%$ for complete loss of conductance, $50 \%$ representing the conductance at $\psi=\psi_{p 50}$ and $100 \%$ representing no loss.

$\Xi=\frac{k}{k_{\max }} \cdot 100$

\section{Results}

\subsection{Reference Evaporation and Transpiration Fluxes}

The reference evaporation $\left(E_{\mathrm{o}}\right)$ approximates the canopy water demand under optimal soil water supply and its mean annual value can be compared to mean annual precipitation $(P)$ to quantify the climatic water stress at a given site. For the selected study sites (Table 2), FR-Pue has the largest annual $E_{\mathrm{o}}\left(921 \mathrm{~mm} \mathrm{yr}^{-1}\right)$ and the largest annual $P\left(915 \mathrm{~mm} \mathrm{yr}^{-1}\right)$, while RU-Fyo has both the smallest annual $E_{\mathrm{o}}\left(480.3 \mathrm{~mm} \mathrm{yr}^{-1}\right)$ and $P\left(405 \mathrm{~mm} \mathrm{yr}^{-1}\right)$. ES-Alt and FR-Hes have similar values of annual $E_{\mathrm{o}}$ (753.5 $\mathrm{mm} \mathrm{yr}^{-1}$ and $728.4 \mathrm{~mm} \mathrm{yr}^{-1}$, respectively), but very different mean annual $P$ (465 and $900 \mathrm{~mm} \mathrm{yr}^{-1}$, respectively), indicating that in ES-Alt the ecosystem is on average water stressed while in FR-Hes is not. At FR-Pue and ES-Alt, the months with the highest $E_{\mathrm{o}}$ are those with the lowest $P$, implying that at these sites the ecosystems are potentially subject to a strong seasonal climatic drought. On the contrary, FR-Hes and RU-Fyo do not experience pronounced dry periods (Fig. 2). Note that annual $E_{\mathrm{o}}$ is not balanced by the annual contribution of $P$ at almost all sites, with the exception of FR-Hes where $P$ exceeds $E_{\mathrm{o}}$. This water deficit may lead important restrictions in soil moisture during dry periods at sites such as FR-Pue and ES-Alt.

The sites of ES-Alt, FR-Hes, and FR-Pue show a similar monthly trend for the maximum vapor pressure deficit (Fig. 2). ESAlt experiences an extended drier period (three months) while RU-Fyo is the only site where the maximum vapor pressure deficit do never surpasses $3 \mathrm{kPa}$. Relationships between $E_{\mathrm{T}}$ and $E_{\mathrm{o}}$ (Fig. 2) illustrate the difference between atmospheric water demand and plant transpiration across the selected sites, where the upscaled $E_{\mathrm{T}}$ represents the integrated effect of environmental constraints (i.e, soil moisture availability and atmospheric demand) on the ecosystem response. RU-Fyo and ES-Alt are the sites with the smallest annual transpiration rates of $81.5 \mathrm{~mm} \mathrm{yr}^{-1}$ and $177 \mathrm{~mm} \mathrm{yr}^{-1}$, respectively (Table 2). 
https://doi.org/10.5194/bg-2021-311

Preprint. Discussion started: 28 January 2022

(c) Author(s) 2022. CC BY 4.0 License.

(c) (i)

The large atmospheric water demand in ES-Alt is not satisfied by the available soil moisture, which defines a soil waterlimited transpiration process. FR-Pue and FR-Hes have a similar annual $E_{\mathrm{T}}$ with values ranging between $329.7 \mathrm{~mm} \mathrm{yr}^{-1} \mathrm{and}^{-}$ $350.1 \mathrm{~mm} \mathrm{yr}^{-1}$, respectively (Table 2).

Daily transpiration rates show differences in terms of timing and magnitude among sites (Fig. 3). FR-Hes has the highest $E_{\mathrm{T}}$ with a peak value of $4.5 \mathrm{~mm} \mathrm{~d}^{-1}$ at the beginning of summer followed by FR-Pue with $2.0 \mathrm{~mm} \mathrm{~d}^{-1}$ at the beginning of June. $E_{\mathrm{T}}$ in FR-Hes shows a quick increment from $0 \mathrm{~mm} \mathrm{~d}^{-1}$ at the beginning of April to more than $2 \mathrm{~mm} \mathrm{~d}^{-1}$ one month later. This increment is directly linked to the leaf flushing period of the dominant tree species ( $F$. sylvatica). $E_{\mathrm{T}}$ declines consistently throughout the summer at all sites, with a striking decline in FR-Pue where the average daily transpiration changes from $1.77 \mathrm{~mm} \mathrm{~d}^{-1}$ to $0.72 \mathrm{~mm} \mathrm{~d}^{-1}$ between June and July. This abrupt pattern shows how the transpiration process is constrained by low soil moisture and large atmospheric water demand. Overall, the temporal analysis of $E_{\mathrm{o}}$ and $E_{\mathrm{T}}$ suggests a pairwise clustering of FR-Hes and RU-Fyo as sites with a more homogeneous temporal distribution of $P$ that controls the atmospheric humidity (Granier et al., 2008). In a similar way, ES-Alt and FR-Pue can be clustered together as soil water-limited sites (Grossiord et al., 2015, 2018) where the large atmospheric moisture deficit is not satisfied by the soil water supply. Altogether, $E_{\mathrm{T}}$ is smaller than $E_{\mathrm{o}}$ in ES-Alt, FR-Pue, and RU-Fyo, with a sudden decline of $E_{\mathrm{T}}$ at FR-Pue and ES-Alt in the middle of the year. FR-Hes transpires almost at $E_{\mathrm{o}}$ in spring and summer. Finally, RU-Fyo transpiration rates are less than $50 \%$ of $E_{\mathrm{o}}$ throughout the season, despite sufficient rainfall to satisfy annual evaporative demand.

\subsection{Modelling Effects of Bedrock Configuration}

Figure 3 shows the multi-annual variability of the measured and simulated daily transpiration fluxes at the selected sites. The visual inspection of these plots illustrates the different capability of CLM 5 to capture the intra- and inter-site variability of the measured transpiration fluxes. In ES-Alt and FR-Pue site, the DMC largely overestimates $E_{\mathrm{T}}$ during spring and underestimates $E_{\mathrm{T}}$ in summer; at both sites the model simulates a sharp decline in $E_{\mathrm{T}}$ at the beginning of summer. The introduction of a deeper (i.e, DBC) and fractured (i.e., FBC) bedrock configuration alleviates the summer underestimation without eliminating the large overestimation during spring. In FR-Hes, the DMC configuration accurately reproduces the magnitude and intraseasonal variability of the measured transpiration fluxes, with a slight overestimation of $E_{\mathrm{T}}$ during early spring and summer. The modified bedrock configurations DBC and FBC slightly increase the summer overestimation of $E_{\mathrm{T}}$ with respect to the default configuration. All three model configurations (i.e., DMC, DBC, and FBC) systematically overestimate $E_{\mathrm{T}}$ in RU-Fyo, with no differences among model configurations.

A quantitative estimation of the performances of the three model configurations is obtained using the index of agreement described in section 3.3.2. Figure 4 shows the monthly variability of the Pearson correlation coefficient (r), $\Gamma$ index, and $\alpha$ coefficient for the three model configurations at the four experimental sites. In the graphical scheme adopted in this figure, the black and green empty circles set the references for $r$ equal to 1 and 0.5 , respectively. The filled circle represents the $\alpha$ 
https://doi.org/10.5194/bg-2021-311

Preprint. Discussion started: 28 January 2022

(c) Author(s) 2022. CC BY 4.0 License.

(c) (i)

coefficient, which down-regulates the size of the coloured circle (i.e., the correlation coefficient) according to the bias between the two data sets while the size of the red circle reflects the resulting value of $\Gamma$. Therefore, the best match between simulated and measured transpiration data is represented by a blue-filled circle with the black and red boundary lines close to each other, that is, $r$ and $\alpha$ coefficients close to 1 (e.g, FR-Hes.DMC.August). On the other hand, when the two data sets have an inverse correlation (i.e., $r<0$ ), $\alpha$ is equal to 0 and no visual representation is used (e.g, ES-Alt.DMC.June). Finally, the case of high correlation and large bias between the two data sets is visualized with a filled circle with a dark-orange color close to the external black boundary line, which results in a red circle (i.e., $\Gamma$ index) reduced in size proportionally to the $\alpha$ value (e.g, ES-Alt.DMC.March).

In ES-Alt, the DMC configuration reproduces the measured transpiration with an $r$ coefficient systematically larger than 0.6 and it peaks around 0.8 for the period between November and May (Table A1). This temporal agreement is, however, concurrent with a large bias, $\alpha$ coefficient ranging between 0.24 and 0.94 , which determines $\Gamma$ values being not larger that 0.57 . The performance of the DMC configuration drastically deteriorates during summer and fall (max $\Gamma$ equals to 0.29 ), where negatively or poorly correlated time series in June, September, and October determine zero or close to zero values of $\Gamma$. Note that during the dry season decent correlation values (i.e, August) are greatly outweighed by the bias between measured and simulated transpiration values (Fig. 4).

285 The performance of the DMC configuration shows less temporal variability at the FR-Pue study site. With the exception of a few months (e.g., December), the correlation $(r)$ and the $\alpha$ index vary between 0.41 and 0.79 and between 0.45 and 0.96 , respectively, with the resulting $\Gamma$ values between 0.25 and 0.69 (Table A1). Although not as strongly as at ES-Alt, the overall performance of the DMC configuration tends to decrease during the dry period (June-September) also at FR-Pue. The performance of the DMC is striking at FR-Hes during the May-October period (Fig. 4), with $r$ coefficient values larger than 0.65, $\alpha$ values larger than 0.85 , and resulting $\Gamma$ index between 0.58 and 0.86 . On the other hand, the DMC performance at FR-Hes is negatively affected by the strong seasonal pattern of vegetation phenology, as the leaf shedding period (November), leaf-less period (December to March), and leaf flushing period (April) have the lowest $\Gamma$ values (0.62, 0.0, and 0.23, respectively). This discrepancy is likely caused by the leaf area index (LAI) used in the model, with values between $0.9 \mathrm{~m}^{2} \mathrm{~m}^{-2}$ and $1.5 \mathrm{~m}^{2} \mathrm{~m}^{-2}$ during the leaf-less period. This results in simulated transpiration when trees on site do not have leaves at all. RU-Fyo is the only experimental site where the capability of the DMC configuration in reproducing the transpiration response is systematically low throughout the year. At this site, the satisfactory performances in terms of temporal correlation (i.e., $r$ ) in April (0.71) and June (0.65) are accompanied by a high bias, which reduces the $\Gamma$ values (i.e., 0.47 and 0.27 , respectively). Overall, the DMC configuration shows systematic model deficiency in reproducing the dry-season (i.e., June-September) transpiration response at Mediterranean sites with relatively high atmospheric water demand and shallow (below $1 \mathrm{~m}$ ) bedrock depth (i.e., Es-Alt and FR-Pue).

Figure 4 shows the impact of adopting different bedrock configurations on the performance skills of the model across the four experimental sites. The visual inspection of the plot reveals that neither of the DBC and FBC configurations alter the 
https://doi.org/10.5194/bg-2021-311

Preprint. Discussion started: 28 January 2022

(c) Author(s) 2022. CC BY 4.0 License.

(c) (i)

model performance during November-May at any of the selected sites. Interestingly, neither the temporal agreement nor the bias are modified by the extended and altered bedrock during this period. At the RU-Fyo site, these two alternative bedrock configurations do not affect the model estimates at all. On the other hand, the two proposed configurations (i.e., DBC and FBC) have a clear impact on the simulated transpiration at ES-Alt and FR-Pue between June and September (Fig. 4). At ESAlt, both configurations improve the $r$ coefficient and the $\Gamma$ index, improving the model's capability to realistically simulate transpiration fluxes. Such improvement is most evident in the late summer (i.e., August and September) and to a lesser extent in October (Fig. 3). In particular, the DBC configuration shows slightly larger $\Gamma$ values in September and October, while FBC improves the modeled transpiration response in July and August (Table A1). The direction of changes introduced by DBC and FBC configurations are less distinct in FR-Pue site. Here, extending the bedrock depth (i.e., FBC configuration) deteriorates the model performance while prescribing a different water holding capacity in the permeable bedrock (i.e., DBC) improves the model response just in August, September, and October. In particular, the improvements obtained using the DBC configuration are mostly explained by better temporal correlation values and marginal changes in model bias. Finally, both modified bedrock configurations at the FR-Hes site decrease the overall fit of the simulated transpiration response. This is particularly clear in August where DBC and FBC configurations drastically decrease the temporal agreement and overestimate the daily cumulative values compared to the estimates of the default (i.e., DMC) model configuration and the measured transpiration values (Fig. $3)$.

\subsection{Plant Response to Water Stress}

Figure 5 illustrates the percent of hydraulic conductance $(\Xi)$ as a function of plant tissue water potential and the distribution of simulated $\Xi$ values during the dry period of the year (i.e., July-September). The shape of these plant vulnerability curves is highly dependent on $\psi_{\mathrm{p} 50}$ (see Equation 6) and the distribution of values indicates the level of water stress at which plants are operating. For instance, under well-watered conditions the plant is unstressed and the experienced water potential is close to 0 , allowing the corresponding plant organ (i.e., xylem and sunlit leaves) to move water at their maximum capacity. As soil water uptake becomes limiting, plant water potential decreases, followed by the xylem (or leaf) conductance, and the vegetation starts experiencing water stress conditions.

The most extreme plant water stress conditions are simulated at ES-Alt, where the model simulates a reduction in the median conductivities to $20 \%$ (xylem) and 10\% (leaves) in August and even below $10 \%$ in September. Extreme plant stress conditions are also simulated by the DMC configuration at FR-Pue experimental sites. At this location, the xylem conductivities are above $80 \%$ of their maximum value for more than half of the simulated time in July, whereas their median value drastically decreases below $30 \%$ in August. The range of water potentials is even more severe at the leaf level, which simulates a drop in the median conductivity from $45 \%$ to $10 \%$ between July and August. The system smoothly recovers in September with medians of $55 \%$ and $30 \%$ of the maximum conductivity for xylem and leaf, respectively. At the FR-Hes site, the DMC configuration results in little to moderate water stress conditions (majority of simulated data is well above $\psi_{\mathrm{p} 50}$, see box plots in Fig. 5), 
https://doi.org/10.5194/bg-2021-311

Preprint. Discussion started: 28 January 2022

(c) Author(s) 2022. CC BY 4.0 License.

(c) (i)

with some outliers due to isolated episodes of extreme heat (e.g., August-2003) and/or dry soil moisture conditions (e.g., July2003). Finally, the analysis of the $\Xi$ at RU-Fyo suggests well-watered soil conditions throughout the year, with xylem and leaf conductivity larger than $95 \%$ of their maximum values.

The effect of deeper or fractured bedrock configurations on simulated plant water status emerges most clearly wherever the default configuration results in severe water stress, i.e. mainly at the Mediterranean sites, ES-Alt and FR-Pue (Fig. 5). At ES-Alt, the DBC shifts the median xylem conductivity to $60-80 \%$ of their maximum, compared to $10-20 \%$ in the default configuration in August-September. The effect of the FBC configuration is similar, but less pronounced at this site. At FR-Pue, the DBC configuration leads to a very strong reduction of water stress compared to the default configuration, with increases of relative xylem conductivity from $15-50 \%$ to $90-100 \%$ in August, and even higher in the other months. The shift is even more clear when inspecting the loss of conductivity simulated at the leaf level. In this case, there is also a drastic change in the inter-quartile range, especially in July and September, suggesting a reduction of the inter-annual variability of vegetation response during the dry season. Yet, the implementation of the FBC at FR-Pue alleviates the harsh conditions simulated by DMC, but the leaves are still affected by a severe plant water status conditions. On the other hand, at FR-Hes and RU-Fyo, where DMC results in little loss of conductance, both the DBC and FBC model do not have any clear effects on the simulated plant water status, except for August and September at FR-Hes, where the rare excursions of relative hydraulic conductivity below the $80 \%$ mark are removed.

\section{Discussion}

Plants rely on structural (e.g., rooting depth, leaf shading) and functional (e.g., stomatal regulation, plant storage capacitance, hydraulic redistribution) strategies to tolerate extended dry periods (Aroca, 2012; Gupta et al., 2020). These strategies depend on the upper (i.e., climate) and lower (i.e., soil and geological) boundary conditions (Fan et al., 2017). If geological conditions allow for the formation of deep soils (e.g., Amazon Basin, Loess Plateau), access to deep groundwater can become very important for surviving extended dry periods (Chitra-Tarak et al., 2021; Tao et al., 2021). As an example, Mediterranean trees are able to uptake water from the deep vadose zone (Carrière et al., 2020) sustaining transpiration during the dry season without being affected by embolism (David et al., 2007, 2013; Prieto and Ryel, 2013). Given the strong effect of transpiration on the land surface energy partitioning (Duveiller et al., 2018; Forzieri et al., 2020), it is important that LSMs correctly represent plant water uptake processes and their link to the magnitude and timing of transpiration. The advanced plant hydraulics representation of CLM 5 simulates the water uptake and transport across the whole plant system (e.g., roots, stems, and leaves). This allows to evaluate the influence of bedrock configuration on the bulk transpiration flux as well as to differentiate its impact on the susceptibility to hydraulic failure of the different plant segments. 
https://doi.org/10.5194/bg-2021-311

Preprint. Discussion started: 28 January 2022

(c) Author(s) 2022. CC BY 4.0 License.

\section{(c) (i)}

(n)

\subsection{Bedrock Effects on Modeled Transpiration}

The rooting profile implemented in CLM 5 follows an exponential distribution, resulting in non-zero root abundance throughout all the way down to the bedrock. The PFTs BDT and BET allocate $95 \%$ of the roots within the first $0.7 \mathrm{~m}$ of soil. Those sites with an impermeable bedrock layer very close to the surface effectively cut off the root distribution at that position, without increasing root abundance in the layers above. This limits drastically the access to water resources forcing the model to use only the water available in the superficial soil layers, affecting transpiration rates and plant hydraulic response under dry conditions. As a result, the DMC configuration restricts the water acquisition of these PFTs at seasonally dry sites, such as ES-Alt and FRPue, by removing almost $10 \%$ of the roots that can provide more than $50 \%$ of transpiration water during summer conditions in dry environments with deeper soils (Carrière et al., 2020; Klos et al., 2018; Hahm et al., 2020; Jiang et al., 2020; Nardini et al., 2021; Qi et al., 2018; Rempe and Dietrich, 2018). The transpiration signal retrieved from sap flow sensors shows how plants are able to access deep water sources during dry periods when compared to $E_{\mathrm{T}}$ as simulated by the DMC configuration. The steep temporal decline of modeled $E_{\mathrm{T}}$ in ES-Alt and FR-Pue during summer contrast significantly with the measured values at both sites (Fig. 3). These differences depict the dry out process of the superficial soil layers carried out by the vegetation due to the lack of access to deep water sources by the modeled vegetation and the absence of $P$ to replenish the transpired soil water. In FR-Hes the limited access of vegetation to deep water sources due to the shallow DTB is counterbalanced by the temporal distribution of $P$ that replenishes the transpired superficial soil water avoiding plant water stress conditions at this site.

The DTB parameterization used in CLM 5 simulations corresponds to a sharp transition between soil and consolidated bedrock assuming this latter as a hydrologically inactive layer (Lawrence et al., 2019) that limits the plant water supply at sites with thin soils and pronounced dry seasons. This assumption neglects the fact that weathered bedrock contains cracks formed by physical and chemical weathering processes (Pawlik et al., 2016; Phillips et al., 2019; Pope, 2015), allowing for accumulation of sediments and increasing its capacity to store water. McCormick et al. (2021) underlined the importance of water stored in the weathered bedrock to fulfill the vegetation physiological needs during the growing season. Similarly, Pelletier et al. (2016) stressed the beneficial effect of adding this intermediate layer in LSMs as a reservoir for plants during dry periods. The high heterogeneity of the underlying subsurface characteristics is critical for quantifying the water budget at the local scale (Blyth et al., 2021) and it determines the large uncertainty on the estimation of the weathered bedrock depth. In our study, moving the DTB $1.5 \mathrm{~m}$ below the initial value allowed the vegetation to access a larger soil water storage. This configuration doubled the summer transpiration flux of the vegetation at ES-Alt and FR-Pue Mediterranean sites and increased of almost $25 \%$ in FR-Hes with respect to the DMC configuration (Table 2).

The large spatial heterogeneity of bedrock saturated conductivity (Welch and Allen, 2014) and the fact that this property depends on the parental material (Huggett, 2007; Summerfield, 1991) increases the difficulty of incorporating this additional bedrock layer in LSMs. As an attempt to reduce this complexity, the FBC configuration proposed in our study modifies the additional water storage added in DBC by changing its soil texture. The clay fraction of DBC is larger than $10 \%$, condition 
https://doi.org/10.5194/bg-2021-311

Preprint. Discussion started: 28 January 2022

(c) Author(s) 2022. CC BY 4.0 License.

(c) (i)

that enhances the soil water storage with respect to FBC which has a larger saturated conductivity than DBC. The assumption of representing a fractured bedrock as a sandy soil is supported by the similarities in saturated hydraulic conductivity $\left(K_{\mathrm{s}}\right)$ that both substrata have. Sandy soils have a $K_{\mathrm{s}}$ of $10^{-4} \mathrm{~m} \mathrm{~s}^{-1}$ (Miyazaki, 1996; Pachepsky and Park, 2015), values that are within the range reported for weathered granite rocks that oscillates between $10^{-2} \mathrm{~m} \mathrm{~s}^{-1}$ to $10^{-5} \mathrm{~m} \mathrm{~s}^{-1}$ (Rouxel et al., 2010; Katsura et al., 2009). The FBC reduces the summer transpiration with respect to DBC in ES-Alt, FR-Pue, and FR-Hes of $18 \%, 24 \%$, and $4 \%$, respectively (Table 2). This reduction of $E_{\mathrm{T}}$ is the consequence of reducing the soil water storage by changing the clay content of the fractured bedrock layer in FBC (Fig. 1). As an example, when switching from DBC to FBC configuration, the clay content in ES-Alt and FR-Pue is changed respectively from $20 \%$ and $40 \%$ to a fixed value of $10 \%$. It is important to underline that the inclusion of $\mathrm{DBC}$ and $\mathrm{FBC}$ leads to no differences in the model transpiration response during winter and spring periods but allow to increase the summer $E_{\mathrm{T}}$ in ES-Alt, FR-Pue, and FR-Hes with respect to DMC.

\subsection{Bedrock and Hydraulic Plant Recovery}

The implementation of plant hydraulics in terrestrial modelling allows to link the plant transpiration to soil water availability and vapor pressure deficit (Bonan et al., 2014; Liu et al., 2020). The photosynthesis drives the plant water needs and forces the plant hydraulic system to extract soil water at a maximum rate when soil water resources are unlimited. CLM 5 uses Equation 6 to represent the plant water supply of different plant organs as a function of gradients in water potentials. In this formulation, $\psi_{\mathrm{p} 50}$ modulates the plant water uptake according to the atmospheric water deficit, plant organ conductivity, and soil matric potential (Lawrence et al., 2019). The segmented application of Equation 6 per soil layer to simulate the root water uptake allows the modeled vegetation to switch the water uptake from dry to wet soil layers (Kennedy et al., 2019). This plant hydraulic formulation provides also the opportunity to diagnose the hydraulic function of the different plant organs (i.e., roots, stems, and leaves) and their susceptibility to hydraulic failure (McCulloh et al., 2019; Meinzer et al., 2009) as part of the model response to environmental stresses.

The three model configurations (i.e., DMC, DBC, and FBC) have a tendency to overestimate $E_{\mathrm{T}}$ during spring in ES-Alt, FR-Pue, and FR-Hes (Fig. 3). This tendency reflects the model transpiration response under unlimited soil water conditions and increasing VPD (Fig. 2 and Fig. A1). Under such conditions the plant hydraulic system extracts soil water to satisfy the atmospheric water demand with the positive feedback of $P$ replenishing the transpired soil water. However, at sites with a superficial DTB and extended periods with a lack of $P$, this mechanism leads to a complete dry-out of the soil profile. The extreme soil water depletion pushes the plant matric potentials well below the $\psi_{\mathrm{p} 50}$ values prescribed for each PFT, generating physiological conditions at which plants hardly survive. As an example, the matric potentials simulated for stems and leaves at FR-Pue and ES-Alt are beyond the safety margins reported for broadleaf tree species (-0.9 MPa and -0.8 MPa for root-tostem and stem-to-leaf, respectively) (Johnson et al., 2012). The inclusion of a deeper and fractured bedrock (i.e., DBC and FBC) alleviates this issue allowing the model to reproduce more realistic plant water potentials and transpiration rates during 
https://doi.org/10.5194/bg-2021-311

Preprint. Discussion started: 28 January 2022

(c) Author(s) 2022. CC BY 4.0 License.

(c) (i)

dry periods at FR-Pue and ES-Alt. The alternative bedrock configurations reduce also the susceptibility to hydraulic failure according to the experienced matric potentials by stems and leaves (Fig. 5).

The current plant hydraulic formulation of CLM 5 assumes a full recovery of the plant also when its organs experience water potentials below $\psi_{\mathrm{p} 50}$; FR-Pue and ES-Alt sites are clear examples of the implications of this assumption with $\Xi$ continuously ranging between $10 \%$ and $100 \%$ at the stem and leaf level in summer (Fig. A2 and Fig. A3). Full recovery after partial failure of the hydraulic system may be possible when plants are adapted to such conditions (Sperry and Love, 2015) despite that after long dry periods the root-to-soil interface becomes a constraint to plant water uptake (Zarebanadkouki et al., 2016) before the soil gets moist again. Some plant species may have strategies to repair embolism damages in their tissues favouring the hydraulic efficiency-safety (Johnson et al., 2012; Klein et al., 2018), but it can not be considered as a norm across all vegetation types. Experimental evidence documented in several studies (Johnson et al., 2018; Klein et al., 2018; Ocheltree et al., 2020; Rehschuh et al., 2020) indicates that plants tissues are affected when their water potentials go below $\psi_{\text {p50 }}$. As a result, the conducting tissues of most of the plant species are not able to recover the pre-drought hydraulic conductivity or experience embolism. This is an important omission in the current plant hydraulic system of CLM 5 that requires further model developments including for instance plant mortality and a hydraulic conductivity recovery following a different vulnerability path.

The uncertainty in the parameterization of $\psi_{\mathrm{p} 50}$ in the plant hydraulic system of CLM 5 can lead to large and systematic errors in the transpiration fluxes. In the RU-Fyo site, the three model configurations overestimate the measured $E_{\mathrm{T}}$ with the same order of magnitude (Table 2) and the same temporal pattern (Fig. 3). This is due to the default $\psi_{\mathrm{p} 50}$ value of $-5.2 \mathrm{MPa}$ (Table 1) assigned to the NET PFT, which differs from the reported values of the tree species monitored at RU-Fyo (i.e., Betula sp., P. abies, and $P$. sylvestris) which have $\psi_{\mathrm{p} 50}$ mean values of $-3.7 \pm 0.3 \mathrm{MPa},-1.5 \pm 0.6 \mathrm{MPa}$, and $-3.1 \pm \dot{0} .5 \mathrm{MPa}$ (Choat et al., 2012). Larger values of $\psi_{\mathrm{p} 50}$ allow the modeled vegetation to extract more soil moisture to fulfill the atmospheric water demand increasing considerably the simulated $E_{\mathrm{t}}$ with respect to the measured one. Finally, the growth of a bog as the main ground cover beneath the canopy in RU-Fyo is an indication of the poor drainage of the site (Vygodskaya et al., 2002). Since it is a poorly drained peatland site, it may be that root water uptake is hampered by water logging and anoxia in the root zone for extended periods of time, and consequently reducing tree transpiration (Angstmann et al., 2013).

\section{Conclusions}

Experimental studies have demonstrated that bedrock-vegetation interactions involve a significant and vital water resource for plants during the dry season which is largely omitted in hydrological and land surface models. This study tested the impact of this omission in a state-of-the art LSM, CLM 5, by comparing the simulated transpiration response of three different bedrock configurations (i.e., default, deeper, and fractured bedrock). The two additional configurations mimic the effect of a deeper impermeable layer as well as the impact of an overlying weathered material on the impermeable bedrock. This overlying 
https://doi.org/10.5194/bg-2021-311

Preprint. Discussion started: 28 January 2022

(c) Author(s) 2022. CC BY 4.0 License.

(c) (i)

weathered bedrock is parameterized assigning a low clay content to account for its water holding capacity while the larger sand content enables quick drainage of water percolating from the soil. The three model configurations were tested at four forested sites included in the SAPFLUXNET measurement network and characterized by a shallow bedrock and contrasting atmospheric water demand.

The results of this study suggest that the presence of a shallow bedrock defined as a hydrological inactive layer (i.e., default model configuration) leads to strongly reduced water availability to plants during prolonged dry seasons and unrealistic water stress in root, xylem, and leaf tissues. The results show also the positive impact, especially at Mediterranean climate sites, of increasing the depth to bedrock and adjusting the clay content to mimic a weathered bedrock; the simulated transpiration significantly increases attaining a better match with the measured seasonal transpiration patterns. Moreover, these two additional configurations (i.e., deeper and fractured bedrock) reduce the water stress experienced by the modeled xylem and leaf plant segments keeping the percentage loss of tissue conductivity above $50 \%$, which is more in line with the range of water potentials at which plants operate. The model default configuration at sites with climates without prolonged dry periods has an optimal performance because the soil water sources are not fully depleted by the ecosystem needs. Moreover, sites with colder temperatures and more humid conditions are not affected by the implemented model configurations. Overall, the proposed weathered bedrock formulation allows the modeled vegetation to make full use of the root profile reducing the negative effect of the large soil control on transpiration when superficial soil layers have been dry out.

This work is a first attempt to understand how the bedrock parameterization of CLM 5 impacts the transpiration and provides some important insights on the sensitivity of the newly developed plant hydraulics system. This scientific issue has been explored by accounting for the uncertainty in the definition of the depth to the bedrock and by altering the texture composition of the soil overlying the impermeable depth. As a first order estimation, this approach provided an assessment on the impact of the additional soil water volume and water holding capacity on the simulated plant conditions. However, as also advocated in previous studies, novel and more advanced parameterizations should also include the physical characterization (e.g., bulk hydraulic conductivity, tortuosity, porosity) of weathered bedrock to represent water movement and storage in a fractured porous media. This will allow for an improved representation of water and nutrient uptake from the soil and weathered bedrock column. Therefore, future studies should focus on identifying the most suitable weathered bedrock representation to be integrated into LSMs as well as to develop novel measurement techniques and strategies for model parameterizations such as rock moisture and water holding capacity at the large scale.

\section{Code availability}

The R scripts used for pre-processing, post processing, and plotting the information are available in ZENODO repository at the following link: https://doi.org/10.5281/zenodo.5153161 (Jiménez-Rodríguez, 2021). 
https://doi.org/10.5194/bg-2021-311

Preprint. Discussion started: 28 January 2022

(C) Author(s) 2022. CC BY 4.0 License.

(c) (i)

\section{Data availability}

Sap flow data is available from the ZENODO repository at the following link: https://doi.org/10.5281/zenodo.3971689 (last access: 20 August 2021) (Poyatos et al., 2020). COSMO-REA 6 data can be downloaded from the opendata-FTP server at DWD at the following link: https://opendata.dwd.de/climate_environment/REA/COSMO_REA6/ (last access: 1 June 2021) (HErZ and DWD, 2020).

Author contributions. César Dionisio Jiménez-Rodríguez (CJR) and Mauro Sulis (MS) designed the numerical experiments. CJR carried out the numerical simulations and led the analysis with input from MS and Stanislaus Schymanki (SS). CJR wrote the manuscript with significant contributions from MS and SS.

Competing interests. The authors declare that they have no conflict of interest.

Acknowledgements. This work is supported by the Luxembourg National Research Fund (FNR) CORE programme (C19/SR/13652816/CAPACITY). 
https://doi.org/10.5194/bg-2021-311

Preprint. Discussion started: 28 January 2022

(c) Author(s) 2022. CC BY 4.0 License.

(c) (i)

\section{References}

Acuña Míguez, B., Valladares, F., and Martín-Forés, I.: Both Mature Patches and Expanding Areas of Juniperus thurifera Forests Are

Vulnerable to Climate Change But for Different Reasons, Forests, 11, https://doi.org/10.3390/f11090960, 2020.

Alagele, S. M., Jose, S., Anderson, S. H., and Udawatta, R. P.: Hydraulic lift: processes, methods, and practical implications for society, Agroforestry Systems, 95, 641-657, https://doi.org/10.1007/s10457-021-00614-w, 2021.

Allard, V., Ourcival, J. M., Rambal, S., Joffre, R., and Rocheteau, A.: Seasonal and annual variation of carbon exchange in an evergreen Mediterranean forest in southern France, Global Change Biology, 14, 714-725, https://doi.org/10.1111/j.1365-2486.2008.01539.x, 2008.

Allen, R. G., Pereira, L. S., Raes, D., Smith, M., et al.: Crop evapotranspiration-Guidelines for computing crop water requirements-FAO Irrigation and drainage paper 56, Fao, Rome, 300, D05 109, 1998.

An, N., Hemmati, S., and Cui, Y.-J.: Assessment of the methods for determining net radiation at different time-scales of meteorological variables, Journal of Rock Mechanics and Geotechnical Engineering, 9, 239-246, https://doi.org/10.1016/j.jrmge.2016.10.004, 2017.

Angstmann, J. L., Ewers, B. E., Barber, J., and Kwon, H.: Testing transpiration controls by quantifying spatial variability along a boreal black spruce forest drainage gradient, Ecohydrology, 6, 783-793, https://doi.org/10.1002/eco.1300, 2013.

Aroca, R.: Plant responses to drought stress, Springer-Verlag, Berlin, https://doi.org/10.1007/978-3-642-32653-0, 2012.

Barbeta, A., Mejía-Chang, M., Ogaya, R., Voltas, J., Dawson, T. E., and Peñuelas, J.: The combined effects of a long-term experimental drought and an extreme drought on the use of plant-water sources in a Mediterranean forest, Global Change Biology, 21, 1213-1225, https://doi.org/10.1111/gcb.12785, 2015.

515 Bayala, J. and Prieto, I.: Water acquisition, sharing and redistribution by roots: applications to agroforestry systems, Plant and Soil, 453, 17-28, https://doi.org/10.1007/s11104-019-04173-z, 2020.

Beck, H. E., Zimmermann, N. E., McVicar, T. R., Vergopolan, N., Berg, A., and Wood, E. F.: Present and future Köppen-Geiger climate classification maps at 1-km resolution, Scientific data, 5, 1-12, https://doi.org/10.1038/sdata.2018.214, 2018.

Blyth, E. M., Arora, V. K., Clark, D. B., Dadson, S. J., De Kauwe, M. G., Lawrence, D. M., Melton, J. R., Pongratz, J., Turton, R. H., Yoshimura, K., et al.: Advances in land surface modelling, Current Climate Change Reports, pp. 1-27, https://doi.org/10.1007/s40641021-00171-5, 2021.

Bollmeyer, C., Keller, J. D., Ohlwein, C., Wahl, S., Crewell, S., Friederichs, P., Hense, A., Keune, J., Kneifel, S., Pscheidt, I., Redl, S., and Steinke, S.: Towards a high-resolution regional reanalysis for the European CORDEX domain, Quarterly Journal of the Royal Meteorological Society, 141, 1-15, https://doi.org/10.1002/qj.2486, 2015.

Bonan, G. B., Levis, S., Kergoat, L., and Oleson, K. W.: Landscapes as patches of plant functional types: An integrating concept for climate and ecosystem models, Global Biogeochemical Cycles, 16, 5-1-5-23, https://doi.org/10.1029/2000GB001360, 2002.

Bonan, G. B., Williams, M., Fisher, R. A., and Oleson, K. W.: Modeling stomatal conductance in the earth system: linking leaf wateruse efficiency and water transport along the soil-plant-atmosphere continuum, Geoscientific Model Development, 7, 2193-2222, https://doi.org/10.5194/gmd-7-2193-2014, 2014.

Brunke, M. A., Broxton, P., Pelletier, J., Gochis, D., Hazenberg, P., Lawrence, D. M., Leung, L. R., Niu, G.-Y., Troch, P. A., and Zeng, X.: Implementing and evaluating variable soil thickness in the Community Land Model, version 4.5 (CLM4. 5), Journal of Climate, 29, 3441-3461, https://doi.org/10.1175/JCLI-D-15-0307.1, 2016. 
https://doi.org/10.5194/bg-2021-311

Preprint. Discussion started: 28 January 2022

(C) Author(s) 2022. CC BY 4.0 License.

\section{(c) (i)}

Cabon, A., Mouillot, F., Lempereur, M., Ourcival, J.-M., Simioni, G., and Limousin, J.-M.: Thinning increases tree growth by delaying drought-induced growth cessation in a Mediterranean evergreen oak coppice, Forest Ecology and Management, 409, 333-342, https://doi.org/10.1016/j.foreco.2017.11.030, 2018.

Cai, G., Carminati, A., Abdalla, M., and Ahmed, M. A.: Soil textures rather than root hairs dominate water uptake and soil-plant hydraulics under drought, Plant Physiology, https://doi.org/10.1093/plphys/kiab271, 2021.

Campoy, A., Ducharne, A., Cheruy, F., Hourdin, F., Polcher, J., and Dupont, J. C.: Response of land surface fluxes and precipitation to different soil bottom hydrological conditions in a general circulation model, Journal of Geophysical Research: Atmospheres, 118, 10,72510,739, https://doi.org/10.1002/jgrd.50627, 2013.

Carcavilla, L., Ruiz, R., and Rodríguez, E.: Guía Geológica del Parque Natural del Alto Tajo. Madrid: Instituto Geológico y Minero de España. 267 p, 2008.

Carminati, A. and Javaux, M.: Soil Rather Than Xylem Vulnerability Controls Stomatal Response to Drought, Trends in Plant Science, 25, 868-880, https://doi.org/10.1016/j.tplants.2020.04.003, 2020.

545 Carrière, S. D., Martin-StPaul, N. K., Cakpo, C. B., Patris, N., Gillon, M., Chalikakis, K., Doussan, C., Olioso, A., Babic, M., Jouineau, A., Simioni, G., and Davi, H.: The role of deep vadose zone water in tree transpiration during drought periods in karst settings - Insights from isotopic tracing and leaf water potential, Science of The Total Environment, 699, 134 332, https://doi.org/10.1016/j.scitotenv.2019.134332, 2020.

Chadburn, S. E., Burke, E. J., Essery, R. L. H., Boike, J., Langer, M., Heikenfeld, M., Cox, P. M., and Friedlingstein, P.: Impact of model developments on present and future simulations of permafrost in a global land-surface model, The Cryosphere, 9, 1505-1521, https://doi.org/10.5194/tc-9-1505-2015, 2015.

Chitra-Tarak, R., Xu, C., Aguilar, S., Anderson-Teixeira, K. J., Chambers, J., Detto, M., Faybishenko, B., Fisher, R. A., Knox, R. G., Koven, C. D., Kueppers, L. M., Kunert, N., Kupers, S. J., McDowell, N. G., Newman, B. D., Paton, S. R., Pérez, R., Ruiz, L., Sack, L., Warren, J. M., Wolfe, B. T., Wright, C., Wright, S. J., Zailaa, J., and McMahon, S. M.: Hydraulically-vulnerable trees survive on deep-water access during droughts in a tropical forest, New Phytologist, 231, https://doi.org/10.1111/nph.17464, 2021.

Choat, B., Jansen, S., Brodribb, T., Cochard, H., Delzon, S., Bhaskar, R., Bucci, S., Feild, T., Gleason, S., Hacke, U., Jacobsen, A., Lens, F., Maherali, H., Martinez-Vilalta, J., Mayr, S., Mencuccini, M., Mitchell, P., Nardini, A., Pittermann, J., Pratt, R., Sperry, J., Westoby, M., Wright, I., and Zanne, A.: Global convergence in the vulnerability of forests to drought, https://doi.org/10.1038/nature11688, 2012.

Cipolla, G., Calabrese, S., Noto, L. V., and Porporato, A.: The role of hydrology on enhanced weathering for carbon sequestration I. Modeling rock-dissolution reactions coupled to plant, soil moisture, and carbon dynamics, Advances in Water Resources, p. 103934, https://doi.org/10.1016/j.advwatres.2021.103934, 2021.

Daniel Epron, Jérome Ngao, and André Granier: Interannual variation of soil respiration in a beech forest ecosystem over a six-year study, Ann. For. Sci., 61, 499-505, https://doi.org/10.1051/forest:2004044, 2004.

David, T. S., Henriques, M. O., Kurz-Besson, C., Nunes, J., Valente, F., Vaz, M., Pereira, J. S., Siegwolf, R., Chaves, M. M., Gazarini, L. C., and David, J. S.: Water-use strategies in two co-occurring Mediterranean evergreen oaks: surviving the summer drought, Tree Physiology, 27, 793-803, https://doi.org/10.1093/treephys/27.6.793, 2007.

David, T. S., Pinto, C. A., Nadezhdina, N., Kurz-Besson, C., Henriques, M. O., Quilhó, T., Cermak, J., Chaves, M. M., Pereira, J. S., and David, J. S.: Root functioning, tree water use and hydraulic redistribution in Quercus suber trees: A modeling approach based on root sap flow, Forest Ecology and Management, 307, 136-146, https://doi.org/10.1016/j.foreco.2013.07.012, 2013. 
https://doi.org/10.5194/bg-2021-311

Preprint. Discussion started: 28 January 2022

(C) Author(s) 2022. CC BY 4.0 License.

(c) (i)

de Rosnay, P. and Polcher, J.: Modelling root water uptake in a complex land surface scheme coupled to a GCM, Hydrology and Earth System Sciences, 2, 239-255, https://doi.org/10.5194/hess-2-239-1998, 1998.

Ding, Y., Nie, Y., Chen, H., Wang, K., and Querejeta, J. I.: Water uptake depth is coordinated with leaf water potential, water-use efficiency and drought vulnerability in karst vegetation, New Phytologist, 229, 1339-1353, https://doi.org/10.1111/nph.16971, 2021.

Duveiller, G., Fasbender, D., and Meroni, M.: Revisiting the concept of a symmetric index of agreement for continuous datasets, Scientific

Reports, 6, 19401, https://doi.org/10.1038/srep19401, 2016.

Duveiller, G., Hooker, J., and Cescatti, A.: The mark of vegetation change on Earth's surface energy balance, Nature communications, 9, 1-12, https://doi.org/10.1038/s41467-017-02810-8, 2018.

Fan, Y., Miguez-Macho, G., Jobbágy, E. G., Jackson, R. B., and Otero-Casal, C.: Hydrologic regulation of plant rooting depth, Proceedings of the National Academy of Sciences, 114, 10 572-10 577, https://doi.org/10.1073/pnas.1712381114, 2017.

580 Fan, Y., Clark, M., Lawrence, D. M., Swenson, S., Band, L. E., Brantley, S. L., Brooks, P. D., Dietrich, W. E., Flores, A., Grant, G., Kirchner, J. W., Mackay, D. S., McDonnell, J. J., Milly, P. C. D., Sullivan, P. L., Tague, C., Ajami, H., Chaney, N., Hartmann, A., Hazenberg, P., McNamara, J., Pelletier, J., Perket, J., Rouholahnejad-Freund, E., Wagener, T., Zeng, X., Beighley, E., Buzan, J., Huang, M., Livneh, B., Mohanty, B. P., Nijssen, B., Safeeq, M., Shen, C., van Verseveld, W., Volk, J., and Yamazaki, D.: Hillslope Hydrology in Global Change Research and Earth System Modeling, Water Resources Research, 55, 1737-1772, https://doi.org/10.1029/2018WR023903, 2019.

Fisher, R. A. and Koven, C. D.: Perspectives on the Future of Land Surface Models and the Challenges of Representing Complex Terrestrial Systems, Journal of Advances in Modeling Earth Systems, 12, e2018MS001 453, https://doi.org/10.1029/2018MS001453, 2020.

Forner, A., Aranda, I., Granier, A., and Valladares, F.: Differential impact of the most extreme drought event over the last half century on growth and sap flow in two coexisting Mediterranean trees, Plant Ecology, 215, 703-709, https://doi.org/10.1007/s11258-014-0351-x, 2014.

590 Forzieri, G., Miralles, D. G., Ciais, P., Alkama, R., Ryu, Y., Duveiller, G., Zhang, K., Robertson, E., Kautz, M., Martens, B., et al.: Increased control of vegetation on global terrestrial energy fluxes, Nature Climate Change, 10, 356-362, https://doi.org/10.1038/s41558-020-0717-0, 2020.

Granda, E., Escudero, A., de la Cruz, M., and Valladares, F.: Juvenile-adult tree associations in a continental Mediterranean ecosystem: no evidence for sustained and general facilitation at increased aridity, Journal of Vegetation Science, 23, 164-175, https://doi.org/10.1111/j.1654-1103.2011.01343.x, 2012.

Granier, A., Biron, P., and Lemoine, D.: Water balance, transpiration and canopy conductance in two beech stands, Agricultural and Forest Meteorology, 100, 291-308, https://doi.org/10.1016/S0168-1923(99)00151-3, 2000.

Granier, A., Reichstein, M., Bréda, N., Janssens, I., Falge, E., Ciais, P., Grünwald, T., Aubinet, M., Berbigier, P., Bernhofer, C., Buchmann, N., Facini, O., Grassi, G., Heinesch, B., Ilvesniemi, H., Keronen, P., Knohl, A., Köstner, B., Lagergren, F., Lindroth, A., Longdoz, B., Loustau, D., Mateus, J., Montagnani, L., Nys, C., Moors, E., Papale, D., Peiffer, M., Pilegaard, K., Pita, G., Pumpanen, J., Rambal, S., Rebmann, C., Rodrigues, A., Seufert, G., Tenhunen, J., Vesala, T., and Wang, Q.: Evidence for soil water control on carbon and water dynamics in European forests during the extremely dry year: 2003, Agricultural and Forest Meteorology, 143, 123-145, https://doi.org/10.1016/j.agrformet.2006.12.004, 2007.

Granier, A., Bréda, N., Longdoz, B., Gross, P., and Ngao, J.: Ten years of fluxes and stand growth in a young beech forest at Hesse, Northeastern France, Annals of Forest Science, 65, 704, https://doi.org/10.1051/forest:2008052, 2008. 
https://doi.org/10.5194/bg-2021-311

Preprint. Discussion started: 28 January 2022

(C) Author(s) 2022. CC BY 4.0 License.

\section{(c) (i)}

Grossiord, C., Forner, A., Gessler, A., Granier, A., Pollastrini, M., Valladares, F., and Bonal, D.: Influence of species interactions on transpiration of Mediterranean tree species during a summer drought, European Journal of Forest Research, 134, 365-376, https://doi.org/10.1007/s10342-014-0857-8, 2015.

Grossiord, C., Sevanto, S., Limousin, J.-M., Meir, P., Mencuccini, M., Pangle, R. E., Pockman, W. T., Salmon, Y., Zweifel, R., and McDowell,

N. G.: Manipulative experiments demonstrate how long-term soil moisture changes alter controls of plant water use, Environmental and Experimental Botany, 152, 19-27, https://doi.org/10.1016/j.envexpbot.2017.12.010, experiments with trees: from seedlings to ecosystems, 2018.

Gupta, A., Rico-Medina, A., and Caño-Delgado, A. I.: The physiology of plant responses to drought, Science, 368, 266-269, https://doi.org/10.1126/science.aaz7614, 2020.

Hahm, W. J., Riebe, C. S., Lukens, C. E., and Araki, S.: Bedrock composition regulates mountain ecosystems and landscape evolution, Proceedings of the National Academy of Sciences, 111, 3338-3343, https://doi.org/10.1073/pnas.1315667111, 2014.

Hahm, W. J., Rempe, D. M., Dralle, D. N., Dawson, T. E., and Dietrich, W. E.: Oak Transpiration Drawn From the Weathered Bedrock Vadose Zone in the Summer Dry Season, Water Resources Research, 56, e2020WR027419, https://doi.org/10.1029/2020WR027419, e2020WR027419 10.1029/2020WR027419, 2020.

HErZ and DWD: HErZ - Hans-Ertel Centre for Weather Research (University of Bonn, Germany) and DWD - Deutscher Wetterdienst: COSMO-REA6, http://reanalysis.meteo.uni-bonn.de/?COSMO-REA6, 2020.

Huggett, R.: Fundamentals of geomorphology, Routledge Fundamentals of Physical Geography, second edn., 2007.

Jackson, R. B., Canadell, J., Ehleringer, J. R., Mooney, H. A., Sala, O. E., and Schulze, E. D.: A global analysis of root distributions for terrestrial biomes, Oecologia, 108, 389-411, https://doi.org/10.1007/BF00333714, 1996.

Jiang, Z., Liu, H., Wang, H., Peng, J., Meersmans, J., Green, S. M., Quine, T. A., Wu, X., and Song, Z.: Bedrock geochemistry influences vegetation growth by regulating the regolith water holding capacity, Nature Communications, 11, 2392, https://doi.org/10.1038/s41467020-16156-1, 2020.

Jiménez-Rodríguez, C. D.: Scripts for data analysis of transpiration rates obtained from point scale simulations with CLM 5.0, https://doi.org/10.5281/zenodo.5153161, 2021.

Johnson, D. M., McCulloh, K. A., Woodruff, D. R., and Meinzer, F. C.: Hydraulic safety margins and embolism reversal in stems and leaves: why are conifers and angiosperms so different?, Plant Science, 195, 48-53, https://doi.org/10.1016/j.plantsci.2012.06.010, 2012.

Johnson, K. M., Jordan, G. J., and Brodribb, T. J.: Wheat leaves embolized by water stress do not recover function upon rewatering, Plant, Cell \& Environment, 41, 2704-2714, https://doi.org/10.1111/pce.13397, 2018.

Katsura, S., Kosugi, K., Mizutani, T., and Mizuyama, T.: Hydraulic Properties of Variously Weathered Granitic Bedrock in Headwater CatchmentsAll rights reserved. No part of this periodical may be reproduced or transmitted in any form or by any means, electronic or mechanical, including photocopying, recording, or any information storage and retrieval system, without permission in writing from the publisher., Vadose Zone Journal, 8, 557-573, https://doi.org/10.2136/vzj2008.0142, 2009.

Kattge, J., Diaz, S., Lavorel, S., Prentice, I. C., Leadley, P., Bönisch, G., Garnier, E., Westoby, M., Reich, P. B., Wright, I. J., et al.: TRY-a global database of plant traits, Global change biology, 17, 2905-2935, https://doi.org/10.1111/j.1365-2486.2011.02451.x, 2011.

640 Kennedy, D., Swenson, S., Oleson, K. W., Lawrence, D. M., Fisher, R., Lola da Costa, A. C., and Gentine, P.: Implementing Plant Hydraulics in the Community Land Model, Version 5, Journal of Advances in Modeling Earth Systems, 11, 485-513, https://doi.org/10.1029/2018MS001500, 2019. 
https://doi.org/10.5194/bg-2021-311

Preprint. Discussion started: 28 January 2022

(c) Author(s) 2022. CC BY 4.0 License.

\section{(c) (i)}

Kirkham, M.: Chapter 20 - The Ascent of Water in Plants, in: Principles of Soil and Plant Water Relations (Second Edition), edited by Kirkham, M., pp. 347-374, Academic Press, Boston, second edition edn., 2014.

Klein, T., Zeppel, M. J., Anderegg, W. R., Bloemen, J., De Kauwe, M. G., Hudson, P., Ruehr, N. K., Powell, T. L., von Arx, G., and Nardini, A.: Xylem embolism refilling and resilience against drought-induced mortality in woody plants: processes and trade-offs, Ecological research, 33, 839-855, https://doi.org/10.1007/s11284-018-1588-y, 2018.

Klos, P. Z., Goulden, M. L., Riebe, C. S., Tague, C. L., O’Geen, A. T., Flinchum, B. A., Safeeq, M., Conklin, M. H., Hart, S. C., Berhe, A. A., Hartsough, P. C., Holbrook, W. S., and Bales, R. C.: Subsurface plant-accessible water in mountain ecosystems with a Mediterranean climate, WIREs Water, 5, e1277, https://doi.org/10.1002/wat2.1277, 2018.

Kurbatova, J., Tatarinov, F., Molchanov, A., Varlagin, A., Avilov, V., Kozlov, D., Ivanov, D., and Valentini, R.: Partitioning of ecosystem respiration in a paludified shallow-peat spruce forest in the southern taiga of European Russia, Environmental Research Letters, 8,045028 , https://doi.org/10.1088/1748-9326/8/4/045028, 2013.

Lawrence, D. M., Fisher, R. A., Koven, C. D., Oleson, K. W., Swenson, S. C., Bonan, G., Collier, N., Ghimire, B., van Kampenhout, L., Kennedy, D., Kluzek, E., Lawrence, P. J., Li, F., Li, H., Lombardozzi, D., Riley, W. J., Sacks, W. J., Shi, M., Vertenstein, M., Wieder, W. R., Xu, C., Ali, A. A., Badger, A. M., Bisht, G., van den Broeke, M., Brunke, M. A., Burns, S. P., Buzan, J., Clark, M., Craig, A., Dahlin, K., Drewniak, B., Fisher, J. B., Flanner, M., Fox, A. M., Gentine, P., Hoffman, F., Keppel-Aleks, G., Knox, R., Kumar, S., Lenaerts, J., Leung, L. R., Lipscomb, W. H., Lu, Y., Pandey, A., Pelletier, J. D., Perket, J., Randerson, J. T., Ricciuto, D. M., Sanderson, B. M., Slater, A., Subin, Z. M., Tang, J., Thomas, R. Q., Val Martin, M., and Zeng, X.: The Community Land Model Version 5: Description of New Features, Benchmarking, and Impact of Forcing Uncertainty, Journal of Advances in Modeling Earth Systems, 11, 4245-4287, https://doi.org/10.1029/2018MS001583, 2019.

Le Goff, N. and Ottorini, J.-M.: Root biomass and biomass increment in a beech (Fagus sylvatica L.) stand in North-East France, Ann. For. Sci., 58, 1-13, https://doi.org/10.1051/forest:2001104, 2001.

Liang, S., Zhao, X., Liu, S., Yuan, W., Cheng, X., Xiao, Z., Zhang, X., Liu, Q., Cheng, J., Tang, H., Qu, Y., Bo, Y., Qu, Y., Ren, H., Yu, K., and Townshend, J.: A long-term Global LAnd Surface Satellite (GLASS) data-set for environmental studies, International Journal of Digital Earth, 6, 5-33, https://doi.org/10.1080/17538947.2013.805262, 2013.

Liang, S., Zhang, X., Xiao, Z., Cheng, J., Liu, Q., and Zhao, X.: Leaf Area Index, pp. 3-31, Springer International Publishing, Cham, https://doi.org/10.1007/978-3-319-02588-9_2, 2014.

Liu, Y., Kumar, M., Katul, G. G., Feng, X., and Konings, A. G.: Plant hydraulics accentuates the effect of atmospheric moisture stress on transpiration, Nature Climate Change, 10, 691-695, https://doi.org/10.1038/s41558-020-0781-5, 2020.

Martín-Moreno, C., Fidalgo Hijano, C., Martín Duque, J., González Martín, J., Zapico Alonso, I., and Laronne, J.: The Ribagorda sand gully (east-central Spain): Sediment yield and human-induced origin, Geomorphology, 224, 122-138, https://doi.org/10.1016/j.geomorph.2014.07.013, 2014.

McCormick, E. L., Dralle, D. N., Hahm, W. J., Tune, A. K., Schmidt, L. M., Chadwick, K. D., and Rempe, D. M.: Widespread woody plant use of water stored in bedrock, Nature, 597, 225-229, https://doi.org/10.1038/s41586-021-03761-3, 2021.

McCulloh, K. A., Domec, J.-C., Johnson, D. M., Smith, D. D., and Meinzer, F. C.: A dynamic yet vulnerable pipeline: Integration and coordination of hydraulic traits across whole plants, Plant, Cell \& Environment, 42, 2789-2807, https://doi.org/10.1111/pce.13607, 2019.

Meinzer, F. C., Johnson, D. M., Lachenbruch, B., McCulloh, K. A., and Woodruff, D. R.: Xylem hydraulic safety margins in woody plants: coordination of stomatal control of xylem tension with hydraulic capacitance, Functional Ecology, 23, 922-930, https://doi.org/10.1111/j.1365-2435.2009.01577.x, 2009. 
https://doi.org/10.5194/bg-2021-311

Preprint. Discussion started: 28 January 2022

(C) Author(s) 2022. CC BY 4.0 License.

Miyazaki, T.: Bulk density dependence of air entry suctions and saturated hydraulic conductivities of soils, Soil Science, 161, 484-490, 1996.

Nardini, A., Petruzzellis, F., Marusig, D., Tomasella, M., Natale, S., Altobelli, A., Calligaris, C., Floriddia, G., Cucchi, F., Forte, E., and Zini, L.: Water 'on the rocks': a summer drink for thirsty trees?, New Phytologist, 229, 199-212, https://doi.org/10.1111/nph.16859, 2021.

Nelson, J. A., Pérez-Priego, O., Zhou, S., Poyatos, R., Zhang, Y., Blanken, P. D., Gimeno, T. E., Wohlfahrt, G., Desai, A. R., Gioli, B.,

Limousin, J.-M., Bonal, D., Paul-Limoges, E., Scott, R. L., Varlagin, A., Fuchs, K., Montagnani, L., Wolf, S., Delpierre, N., Berveiller,

D., Gharun, M., Belelli Marchesini, L., Gianelle, D., Šigut, L., Mammarella, I., Siebicke, L., Andrew Black, T., Knohl, A., Hörtnagl, L., Magliulo, V., Besnard, S., Weber, U., Carvalhais, N., Migliavacca, M., Reichstein, M., and Jung, M.: Ecosystem transpiration and evaporation: Insights from three water flux partitioning methods across FLUXNET sites, Global Change Biology, 26, 6916-6930, https://doi.org/10.1111/gcb.15314, 2020.

Niu, G.-Y., Yang, Z.-L., Mitchell, K. E., Chen, F., Ek, M. B., Barlage, M., Kumar, A., Manning, K., Niyogi, D., Rosero, E., Tewari, M., and Xia, Y.: The community Noah land surface model with multiparameterization options (Noah-MP): 1. Model description and evaluation with local-scale measurements, Journal of Geophysical Research: Atmospheres, 116, https://doi.org/10.1029/2010JD015139, 2011.

Novenko, E. and Zuganova, I.: Landscape Dynamics in the Eemian Interglacial and Early Weichselian Glacial Epoch on the South Valdai Hills (Russia), The Open Geography Journal, 3, 44-54, https://doi.org/10.2174/1874923201003010044, 2010.

Ocheltree, T., Gleason, S., Cao, K.-F., and Jiang, G.-F.: Loss and recovery of leaf hydraulic conductance: Root pressure, embolism, and extra-xylary resistance, Journal of Plant Hydraulics, 7, https://doi.org/10.20870/jph.2020.e-001, 2020.

Pachepsky, Y. and Park, Y.: Saturated Hydraulic Conductivity of US Soils Grouped According to Textural Class and Bulk Density, Soil Science Society of America Journal, 79, 1094-1100, https://doi.org/10.2136/sssaj2015.02.0067, 2015.

Pallardy, S. G.: CHAPTER 11 - Absorption of Water and Ascent of Sap, in: Physiology of Woody Plants (Third Edition), edited by Pallardy, S. G., pp. 287-323, Academic Press, San Diego, third edition edn., https://doi.org/10.1016/B978-012088765-1.50012-9, 2008.

Pawlik, Ł., Phillips, J. D., and S̆amonil, P.: Roots, rock, and regolith: Biomechanical and biochemical weathering by trees and its impact on hillslopes-A critical literature review, Earth-Science Reviews, 159, 142-159, https://doi.org/10.1016/j.earscirev.2016.06.002, 2016.

Pelletier, J. D., Broxton, P. D., Hazenberg, P., Zeng, X., Troch, P. A., Niu, G.-Y., Williams, Z., Brunke, M. A., and Gochis, D.: A gridded global data set of soil, intact regolith, and sedimentary deposit thicknesses for regional and global land surface modeling, Journal of Advances in Modeling Earth Systems, 8, 41-65, https://doi.org/10.1002/2015MS000526, 2016.

Phillips, J. D., Pawlik, Ł., and S̆amonil, P.: Weathering fronts, Earth-Science Reviews, 198, 102925, https://doi.org/10.1016/j.earscirev.2019.102925, 2019.

Pope, G. A.: Chapter 4 - Regolith and Weathering (Rock Decay) in the Critical Zone, vol. 19 of Developments in Earth Surface Processes, pp. 113-145, Elsevier, https://doi.org/10.1016/B978-0-444-63369-9.00004-5, 2015.

Poyatos, R., Granda, V., Molowny-Horas, R., Mencuccini, M., Steppe, K., and Mart $\sqrt{ } \neq$ nez-Vilalta, J.: SAPFLUXNET: towards a global database of sap flow measurements, Tree Physiology, 36, 1449-1455, https://doi.org/10.1093/treephys/tpw110, 2016.

Poyatos, R., Granda, V., Flo, V., Molowny-Horas, R., Steppe, K., Mencuccini, M., and Martínez-Vilalta, J.: SAPFLUXNET: A global database of sap flow measurements, https://doi.org/10.5281/zenodo.3971689, 2020.

Poyatos, R., Granda, V., Flo, V., Adams, M. A., Adorján, B., Aguadé, D., Aidar, M. P. M., Allen, S., Alvarado-Barrientos, M. S., AndersonTeixeira, K. J., Aparecido, L. M., Arain, M. A., Aranda, I., Asbjornsen, H., Baxter, R., Beamesderfer, E., Berry, Z. C., Berveiller, D., Blakely, B., Boggs, J., Bohrer, G., Bolstad, P. V., Bonal, D., Bracho, R., Brito, P., Brodeur, J., Casanoves, F., Chave, J., Chen, H., Cisneros, C., Clark, K., Cremonese, E., Dang, H., David, J. S., David, T. S., Delpierre, N., Desai, A. R., Do, F. C., Dohnal, M., Domec, J.-C., Dzikiti, S., Edgar, C., Eichstaedt, R., El-Madany, T. S., Elbers, J., Eller, C. B., Euskirchen, E. S., Ewers, B., Fonti, P., Forner, A., Forrester, 
https://doi.org/10.5194/bg-2021-311

Preprint. Discussion started: 28 January 2022

(c) Author(s) 2022. CC BY 4.0 License.

\section{(c) (i)}

D. I., Freitas, H. C., Galvagno, M., Garcia-Tejera, O., Ghimire, C. P., Gimeno, T. E., Grace, J., Granier, A., Griebel, A., Guangyu, Y.,

Gush, M. B., Hanson, P. J., Hasselquist, N. J., Heinrich, I., Hernandez-Santana, V., Herrmann, V., Hölttä, T., Holwerda, F., Irvine, J., Isarangkool Na Ayutthaya, S., Jarvis, P. G., Jochheim, H., Joly, C. A., Kaplick, J., Kim, H. S., Klemedtsson, L., Kropp, H., Lagergren, F., Lane, P., Lang, P., Lapenas, A., Lechuga, V., Lee, M., Leuschner, C., Limousin, J.-M., Linares, J. C., Linderson, M.-L., Lindroth, A., Llorens, P., López-Bernal, A., Loranty, M. M., Lüttschwager, D., Macinnis-Ng, C., Maréchaux, I., Martin, T. A., Matheny, A., McDowell, N., McMahon, S., Meir, P., Mészáros, I., Migliavacca, M., Mitchell, P., Mölder, M., Montagnani, L., Moore, G. W., Nakada, R., Niu, F., Nolan, R. H., Norby, R., Novick, K., Oberhuber, W., Obojes, N., Oishi, A. C., Oliveira, R. S., Oren, R., Ourcival, J.-M., Paljakka, T., PerezPriego, O., Peri, P. L., Peters, R. L., Pfautsch, S., Pockman, W. T., Preisler, Y., Rascher, K., Robinson, G., Rocha, H., Rocheteau, A., Röll, A., Rosado, B. H. P., Rowland, L., Rubtsov, A. V., Sabaté, S., Salmon, Y., Salomón, R. L., Sánchez-Costa, E., Schäfer, K. V. R., Schuldt, B., Shashkin, A., Stahl, C., Stojanović, M., Suárez, J. C., Sun, G., Szatniewska, J., Tatarinov, F., Tesař, M., Thomas, F. M., Tor-ngern, P., Urban, J., Valladares, F., van der Tol, C., van Meerveld, I., Varlagin, A., Voigt, H., Warren, J., Werner, C., Werner, W., Wieser, G., Wingate, L., Wullschleger, S., Yi, K., Zweifel, R., Steppe, K., Mencuccini, M., and Martínez-Vilalta, J.: Global transpiration data from sap flow measurements: the SAPFLUXNET database, Earth System Science Data, 13, 2607-2649, https://doi.org/10.5194/essd-13-2607-2021, 2021.

Prieto, I. and Ryel, R. J.: Internal hydraulic redistribution prevents the loss of root conductivity during drought, Tree Physiology, 34, 39-48, https://doi.org/10.1093/treephys/tpt115, 2013.

Qi, J., Markewitz, D., and Radcliffe, D.: Modelling the effect of changing precipitation inputs on deep soil water utilization, Hydrological Processes, 32, 672-686, https://doi.org/10.1002/hyp.11452, 2018.

Querejeta, J. I., Estrada-Medina, H., Allen, M. F., and Jiménez-Osornio, J. J.: Water source partitioning among trees growing on shallow karst soils in a seasonally dry tropical climate, Oecologia, 152, 26-36, https://doi.org/10.1007/s00442-006-0629-3, 2007.

Rehschuh, R., Cecilia, A., Zuber, M., Faragó, T., Baumbach, T., Hartmann, H., Jansen, S., Mayr, S., and Ruehr, N.: Drought-induced xylem embolism limits the recovery of leaf gas exchange in Scots pine, Plant physiology, 184, 852-864, https://doi.org/10.1104/pp.20.00407, 2020.

Reichstein, M., Tenhunen, J. D., Roupsard, O., Ourcival, J.-M., Rambal, S., Dore, S., and Valentini, R.: Ecosystem respiration in two Mediterranean evergreen Holm Oak forests: drought effects and decomposition dynamics, Functional Ecology, 16, 27-39, https://doi.org/10.1046/j.0269-8463.2001.00597.x, 2002.

Rempe, D. M. and Dietrich, W. E.: Direct observations of rock moisture, a hidden component of the hydrologic cycle, Proceedings of the National Academy of Sciences, 115, 2664-2669, https://doi.org/10.1073/pnas.1800141115, 2018.

Rouxel, M., Molénat, J., Ruiz, L., Chirié, G., and Hamon, Y.: Determination of saturated and unsaturated hydraulic conductivities and water retention curves of weathered granite, in: EGU General Assembly Conference Abstracts, EGU General Assembly Conference Abstracts, p. 3623, 2010.

Schulze, E.-D., Vygodskaya, N., Tchebakova, N., Czimczik, C., Kozlov, D., Lloyd, J., Mollicone, D., Parfenova, E., Sidorov, K., Varlagin, A., and Wirth, C.: The Eurosiberian Transect: an introduction to the experiment region., Tellus: Series B, 54, 421, http://proxy.bnl.lu/ $\operatorname{login}$ ?URL=http://search.ebscohost.com/login.aspx?direct=true \&db=a9h\&AN=8990406\&site=ehost-live\&scope=site, 2002.

Schwinning, S.: The ecohydrology of roots in rocks, Ecohydrology, 3, 238-245, https://doi.org/10.1002/eco.134, 2010.

Shahin, O., Paul, N. M.-S., Rambal, S., Joffre, R., and Richard, F.: Ectomycorrhizal fungal diversity in Quercus ilex Mediterranean woodlands: variation among sites and over soil depth profiles in hyphal exploration types, species richness and community composition, Symbiosis, 61, 1-12, https://doi.org/10.1007/s13199-013-0252-0, 2013. 
https://doi.org/10.5194/bg-2021-311

Preprint. Discussion started: 28 January 2022

(c) Author(s) 2022. CC BY 4.0 License.

(c) (i)

Shangguan, W., Hengl, T., Mendes de Jesus, J., Yuan, H., and Dai, Y.: Mapping the global depth to bedrock for land surface modeling, Journal of Advances in Modeling Earth Systems, 9, 65-88, https://doi.org/10.1002/2016MS000686, 2017.

Sperry, J., Hacke, U., Oren, R., and Comstock, J.: Water deficits and hydraulic limits to leaf water supply, Plant, cell \& environment, 25, 251-263, https://doi.org/10.1046/j.0016-8025.2001.00799.x, 2002.

Sperry, J. S. and Love, D. M.: What plant hydraulics can tell us about responses to climate-change droughts, New Phytologist, 207, 14-27, https://doi.org/10.1111/nph.13354, 2015.

Sperry, J. S., Adler, F. R., Campbell, G. S., and Comstock, J. P.: Limitation of plant water use by rhizosphere and xylem conductance: results from a model, Plant, Cell \& Environment, 21, 347-359, https://doi.org/10.1046/j.1365-3040.1998.00287.x, 1998.

Sternberg, P., Anderson, M., Graham, R., Beyers, J., and Tice, K.: Root distribution and seasonal water status in weathered granitic bedrock under chaparral, Geoderma, 72, 89-98, https://doi.org/10.1016/0016-7061(96)00019-5, 1996.

Summerfield, M.: Global Geomorphology, Longman, 1991.

Sun, Y., Goll, D. S., Chang, J., Ciais, P., Guenet, B., Helfenstein, J., Huang, Y., Lauerwald, R., Maignan, F., Naipal, V., Wang, Y., Yang, H., and Zhang, H.: Global evaluation of the nutrient-enabled version of the land surface model ORCHIDEE-CNP v1.2 (r5986), Geoscientific Model Development, 14, 1987-2010, https://doi.org/10.5194/gmd-14-1987-2021, 2021.

Swaffer, B. A., Holland, K. L., Doody, T. M., Li, C., and Hutson, J.: Water use strategies of two co-occurring tree species in a semi-arid karst environment, Hydrological Processes, 28, 2003-2017, https://doi.org/10.1002/hyp.9739, 2014.

Swenson, S. C. and Lawrence, D. M.: A GRACE-based assessment of interannual groundwater dynamics in the Community Land Model, Water Resources Research, 51, 8817-8833, https://doi.org/10.1002/2015WR017582, 2015.

Tao, Z., Neil, E., and Si, B.: Determining deep root water uptake patterns with tree age in the Chinese loess area, Agricultural Water Management, 249, 106 810, https://doi.org/10.1016/j.agwat.2021.106810, 2021.

S̆amonil, P., Phillips, J., Danĕk, P., Beneš, V., and Pawlik, Ł.: Soil, regolith, and weathered rock: Theoretical concepts and evolution in old-growth temperate forests, Central Europe, Geoderma, 368, 114 261, https://doi.org/10.1016/j.geoderma.2020.114261, 2020.

van der Laan, S., van der Laan-Luijkx, I., Rödenbeck, C., Varlagin, A., Shironya, I., Neubert, R., Ramonet, M., and Meijer, H.: Atmospheric $\mathrm{CO} 2, \delta(\mathrm{O} 2 / \mathrm{N} 2)$, APO and oxidative ratios from aircraft flask samples over Fyodorovskoye, Western Russia, Atmospheric Environment, 97, 174-181, https://doi.org/10.1016/j.atmosenv.2014.08.022, 2014.

Vrettas, M. D. and Fung, I. Y.: Sensitivity of transpiration to subsurface properties: Exploration with a 1-D model, Journal of Advances in Modeling Earth Systems, 9, 1030-1045, https://doi.org/10.1002/2016MS000901, 2017.

Vygodskaya, N. N., Schulze, E.-D., Tchebakova, N., Karpachevskii, L. O., Kozlov, D., Sidorov, K. N., Panfyorov, M., Abrazko, M., Shaposhnikov, E., Solnzeva, O., Minaeva, T., Jeltuchin, A., Wirth, C., and Pugachevskii, A.: Climate control of stand thinning in unmanaged spruce forests of the southern taiga in European Russia., Tellus: Series B, 54, 443, http://proxy.bnl.lu/login?URL=http: //search.ebscohost.com/login.aspx ?direct=true\&db=a9h\&AN=8990529\&site=ehost-live\&scope=site, 2002.

Welch, L. and Allen, D.: Hydraulic conductivity characteristics in mountains and implications for conceptualizing bedrock groundwater flow, Hydrogeology Journal, 22, 1003-1026, https://doi.org/10.1007/s10040-014-1121-5, 2014.

Zapico, I., Laronne, J. B., Martín-Moreno, C., Martín-Duque, J. F., Ortega, A., and Sánchez-Castillo, L.: Baseline to Evaluate Off-Site Suspended Sediment-Related Mining Effects in the Alto Tajo Natural Park, Spain, Land Degradation \& Development, 28, 232-242, https://doi.org/10.1002/ldr.2605, 2017.

Zarebanadkouki, M., Ahmed, M. A., and Carminati, A.: Hydraulic conductivity of the root-soil interface of lupin in sandy soil after drying and rewetting, Plant and Soil, 398, 267-280, https://doi.org/10.1007/s11104-015-2668-1, 2016. 
https://doi.org/10.5194/bg-2021-311

Preprint. Discussion started: 28 January 2022

(c) Author(s) 2022. CC BY 4.0 License.

Zhang, Z., Li, M., Si, B., and Feng, H.: Deep rooted apple trees decrease groundwater recharge in the highland region of the Loess Plateau,

China, Science of The Total Environment, 622-623, 584-593, https://doi.org/10.1016/j.scitotenv.2017.11.230, 2018.

Table 1. Model parameters used by the three model configurations at the four experimental sites, including the standard deviation variability of daily transpiration estimates $\left(E_{\mathrm{T}-\sigma}\right)$ computed for each site.

\begin{tabular}{|c|c|c|c|c|c|c|}
\hline & & & ES-Alt & FR-Pue & FR-Hes & RU-Fyo \\
\hline \multirow{7}{*}{ 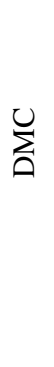 } & Plant Functional Type & & BET & BET & BDT & NET \\
\hline & Root Distribution Parameter & $\beta$ & 0.966 & 0.966 & 0.966 & 0.976 \\
\hline & Water potential at $50 \%$ loss of conductivity & $\mathrm{p} 50$ & $-2.648 \mathrm{MPa}$ & $-2.648 \mathrm{MPa}$ & $-2.648 \mathrm{MPa}$ & $-5.197 \mathrm{MPa}$ \\
\hline & Maximum stem conductivity & $k_{\max }$ & $2 \mathrm{~m} \mathrm{~s}^{-1}$ & $2 \mathrm{~ms}^{-1}$ & $2 \mathrm{~ms}^{-1}$ & $2 \mathrm{~m} \mathrm{~s}^{-1}$ \\
\hline & Shape fitting parameter for & $c_{\mathrm{k}}$ & 3.95 & 3.95 & 3.95 & 3.95 \\
\hline & Soil Texture & & Loam I Clay-Loam & Silty-Clay-Loam & Loam I Clay-Loam & Loam \\
\hline & Bedrock Depth & $z_{\mathrm{brck}}$ & $0.821 \mathrm{~m}$ & $0.945 \mathrm{~m}$ & $1.016 \mathrm{~m}$ & $1.32 \mathrm{~m}$ \\
\hline \multirow{2}{*}{ 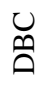 } & Soil Texture (New Soil Layers) & & Loam & Silty-Clay-Loam & Loam & Sandy-Loam \\
\hline & Bedrock Depth & $z_{\text {brck }}$ & $2.321 \mathrm{~m}$ & $2.445 \mathrm{~m}$ & $2.516 \mathrm{~m}$ & $2.82 \mathrm{~m}$ \\
\hline \multirow{2}{*}{$\begin{array}{l}\text { U } \\
\text { II }\end{array}$} & Soil Texture (Mimicked Fractured Bedrock) & & Sandy & Sandy & Sandy & Sandy \\
\hline & Bedrock Depth & $z_{\text {brck }}$ & $2.321 \mathrm{~m}$ & $2.445 \mathrm{~m}$ & $2.516 \mathrm{~m}$ & $2.82 \mathrm{~m}$ \\
\hline \multirow{3}{*}{ 咸 } & Maximum Daily Standard Deviation & $\sigma_{\max }$ & $1.06 \mathrm{~mm} \mathrm{~d}^{-1}$ & $3.53 \mathrm{~mm} \mathrm{~d}^{-1}$ & $4.30 \mathrm{~mm} \mathrm{~d}^{-1}$ & $0.94 \mathrm{~mm} \mathrm{~d}^{-1}$ \\
\hline & Mean Daily Standard Deviation & $\sigma_{\text {mean }}$ & $0.42 \mathrm{~mm} \mathrm{~d}^{-1}$ & $0.34 \mathrm{~mm} \mathrm{~d}^{-1}$ & $0.71 \mathrm{~mm} \mathrm{~d}^{-1}$ & $0.30 \mathrm{~mm} \mathrm{~d}^{-1}$ \\
\hline & Median Daily Standard Deviation & $\sigma_{\text {median }}$ & $0.35 \mathrm{~mm} \mathrm{~d}^{-1}$ & $0.29 \mathrm{~mm} \mathrm{~d}^{-1}$ & $0.62 \mathrm{~mm} \mathrm{~d}^{-1}$ & $0.26 \mathrm{~mm} \mathrm{~d}^{-1}$ \\
\hline
\end{tabular}


https://doi.org/10.5194/bg-2021-311

Preprint. Discussion started: 28 January 2022

(c) Author(s) 2022. CC BY 4.0 License.

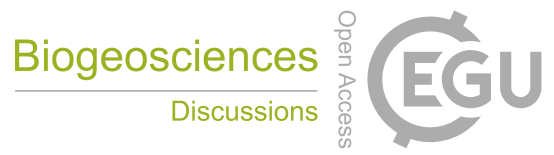

(c) (1)

Table 2. Mean annual estimates of potential evaporation $\left(E_{\mathrm{o}}\right)$, stand transpiration $\left(E_{\mathrm{T}}\right)$, and precipitation $(P)$ per study site. Mean accumulated values of the modeled transpiration for the period under analysis (July to September) for the three bedrock configurations (DMC, DBC, and FBC).

\begin{tabular}{|c|c|c|c|c|c|}
\hline & & ES-Alt & FR-Pue & FR-Hes & RU-Fyo \\
\hline$E_{\mathrm{o}}$ & {$\left[\mathrm{mm} \mathrm{yr}^{-1}\right]$} & $753.5 \pm 62.9$ & $921.2 \pm 43.1$ & $728.4 \pm 99.5$ & $480.3 \pm 88.1$ \\
\hline$E_{\mathrm{T}}$ & {$\left[\mathrm{mm} \mathrm{yr}^{-1}\right]$} & $177 \pm 10.2$ & $329.7 \pm 39.7$ & $350.1 \pm 68.2$ & $81.5 \pm 29.3$ \\
\hline$P$ & {$\left[\mathrm{~mm} \mathrm{yr}^{-1}\right]$} & $465.4 \pm 99.7$ & $914.7 \pm 228.3$ & $900.3 \pm 231.6$ & $404.6 \pm 45.0$ \\
\hline \multicolumn{6}{|c|}{ Period: July to September } \\
\hline$P$ & {$[\mathrm{~mm}]$} & $41.4 \pm 13.3$ & $147.9 \pm 56.8$ & $244.6 \pm 79.4$ & $148.6 \pm 63.7$ \\
\hline$E_{\mathrm{o}}$ & {$[\mathrm{mm}]$} & $380.8 \pm 18.1$ & $396.0 \pm 26.8$ & $316.0 \pm 66.1$ & $240.8 \pm 48.2$ \\
\hline$E_{\mathrm{T}}$ & {$[\mathrm{mm}]$} & $59.7 \pm 17.6$ & $82.3 \pm 18.9$ & $170.5 \pm 44.3$ & $37.9 \pm 20.6$ \\
\hline$E_{\mathrm{T}-\mathrm{DMC}}$ & {$[\mathrm{mm}]$} & $37.8 \pm 30.2$ & $74.1 \pm 26.6$ & $188.1 \pm 35.5$ & $82.7 \pm 3.0$ \\
\hline$E_{\mathrm{T}-\mathrm{DBC}}$ & {$[\mathrm{mm}]$} & $88.4 \pm 39.7$ & $171.3 \pm 35.0$ & $231.9 \pm 17.6$ & $82.7 \pm 3.0$ \\
\hline$E_{\mathrm{T}-\mathrm{FBC}}$ & {$[\mathrm{mm}]$} & $72.9 \pm 46.8$ & $129.4 \pm 42.9$ & $222.5 \pm 11.6$ & $82.7 \pm 3.0$ \\
\hline Years & & 3 & 10 & 5 & 3 \\
\hline
\end{tabular}


https://doi.org/10.5194/bg-2021-311

Preprint. Discussion started: 28 January 2022

(c) Author(s) 2022. CC BY 4.0 License.
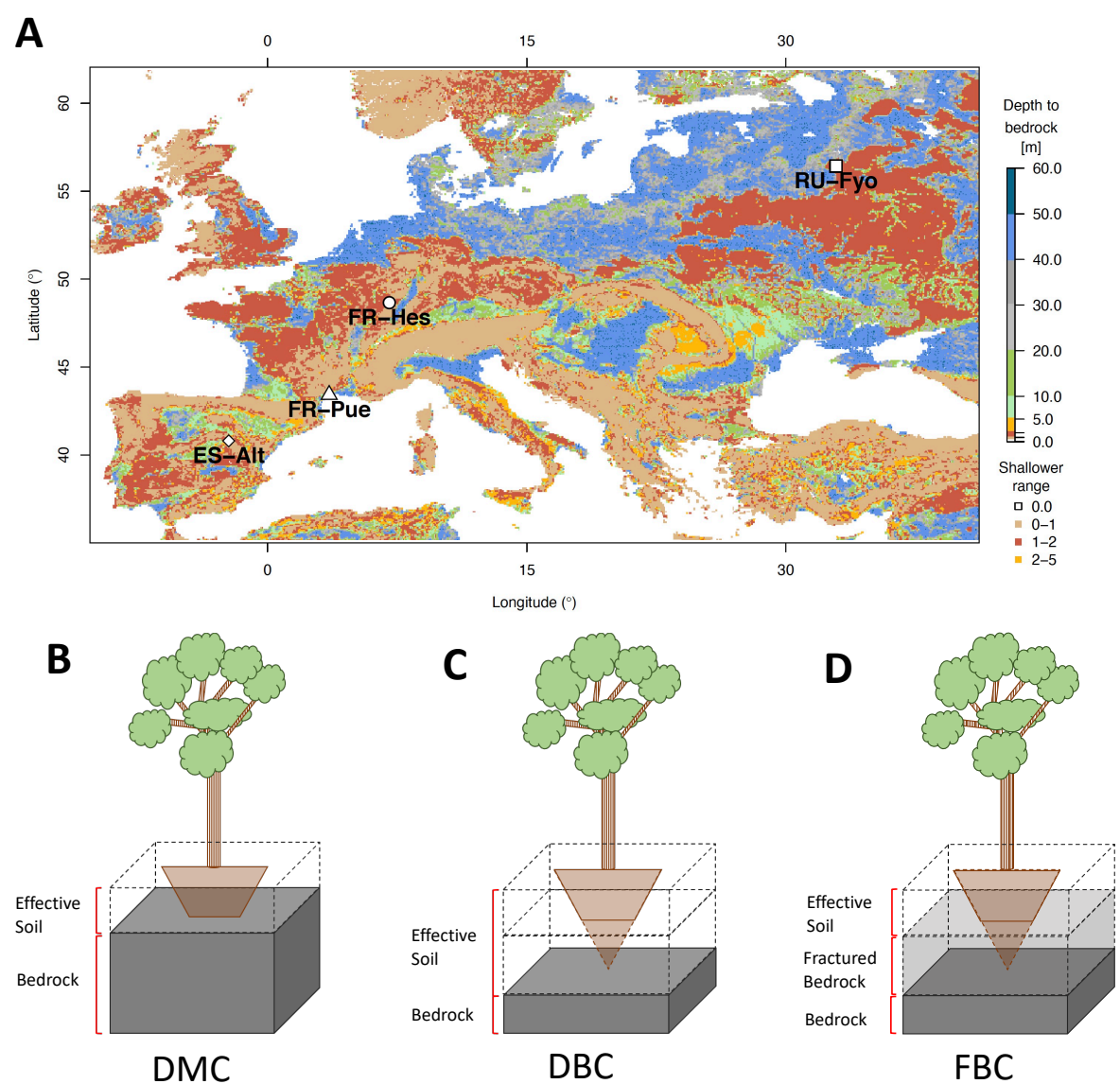

Figure 1. Geographical location of the experimental sites and spatial distribution of the depth to bedrock across Europe (A) based on Pelletier et al. (2016). Schematic of the three bedrock representations: default model configuration, DMC (B); deeper bedrock configuration, DBC (C); and fractured bedrock configuration, FBC (D). 
https://doi.org/10.5194/bg-2021-311

Preprint. Discussion started: 28 January 2022

(c) Author(s) 2022. CC BY 4.0 License.

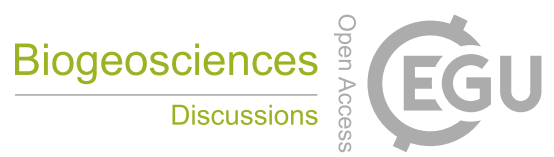

(c) (i)
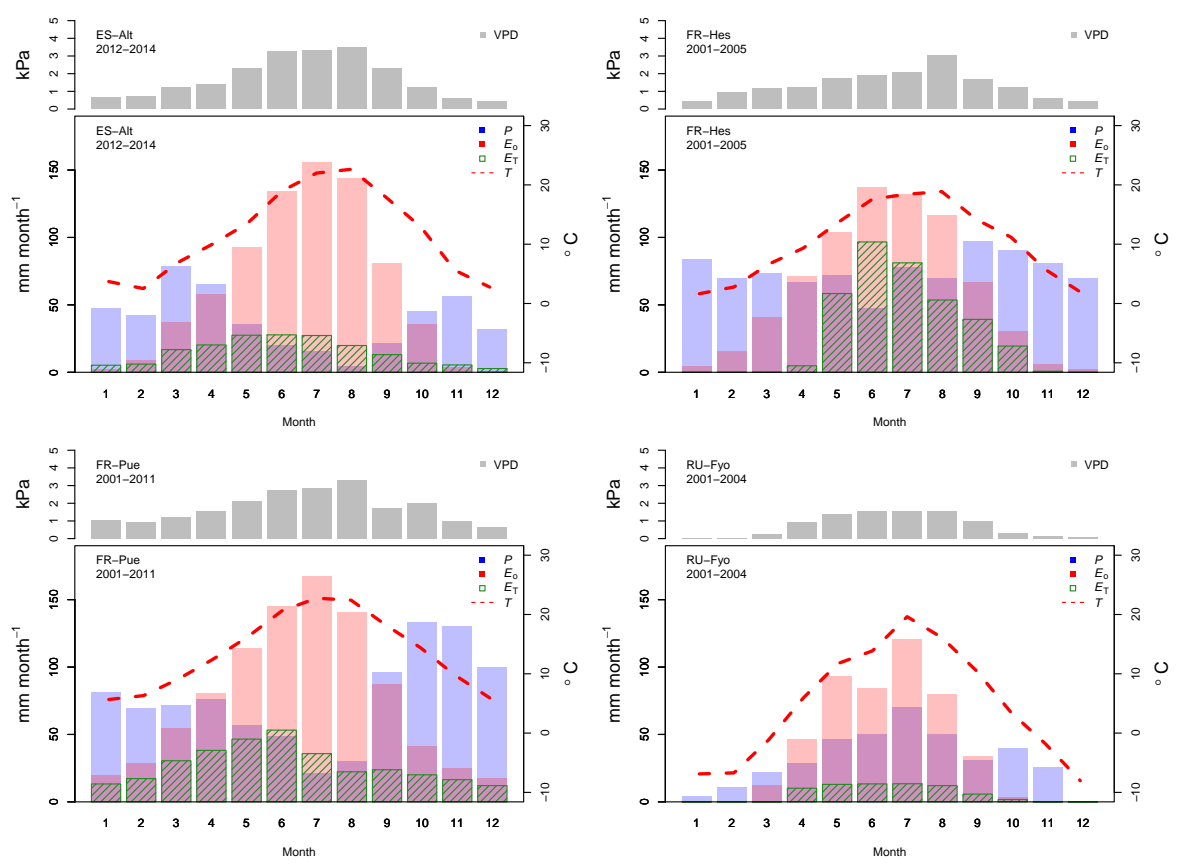

Figure 2. Monthly variation of maximum vapor pressure deficit (VPD), precipitation $(P)$, potential evaporation $\left(E_{\mathrm{o}}\right)$, measured transpiration $\left(E_{\mathrm{T}}\right)$ and air temperature $(T)$ for the selected experimental sites across Europe. Monthly averages are based on the different sampling periods for each site. 
https://doi.org/10.5194/bg-2021-311

Preprint. Discussion started: 28 January 2022

(c) Author(s) 2022. CC BY 4.0 License.
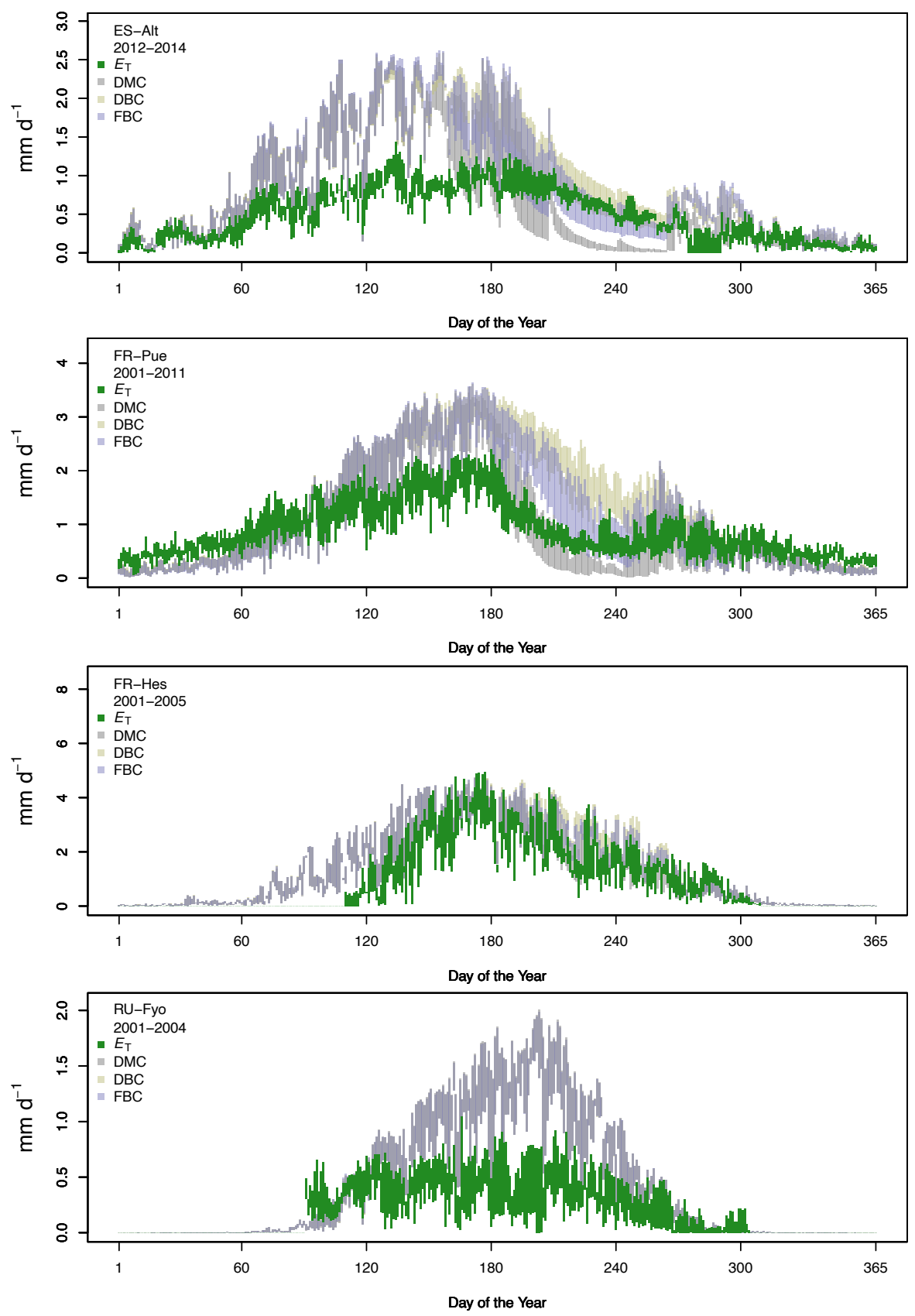

Figure 3. Measured and modeled daily transpiration rates for the different model configurations at each experimental site. The boxes indicate the inter-annual variability at the selected sites. 
https://doi.org/10.5194/bg-2021-311

Preprint. Discussion started: 28 January 2022

(c) Author(s) 2022. CC BY 4.0 License.

(c) (i)
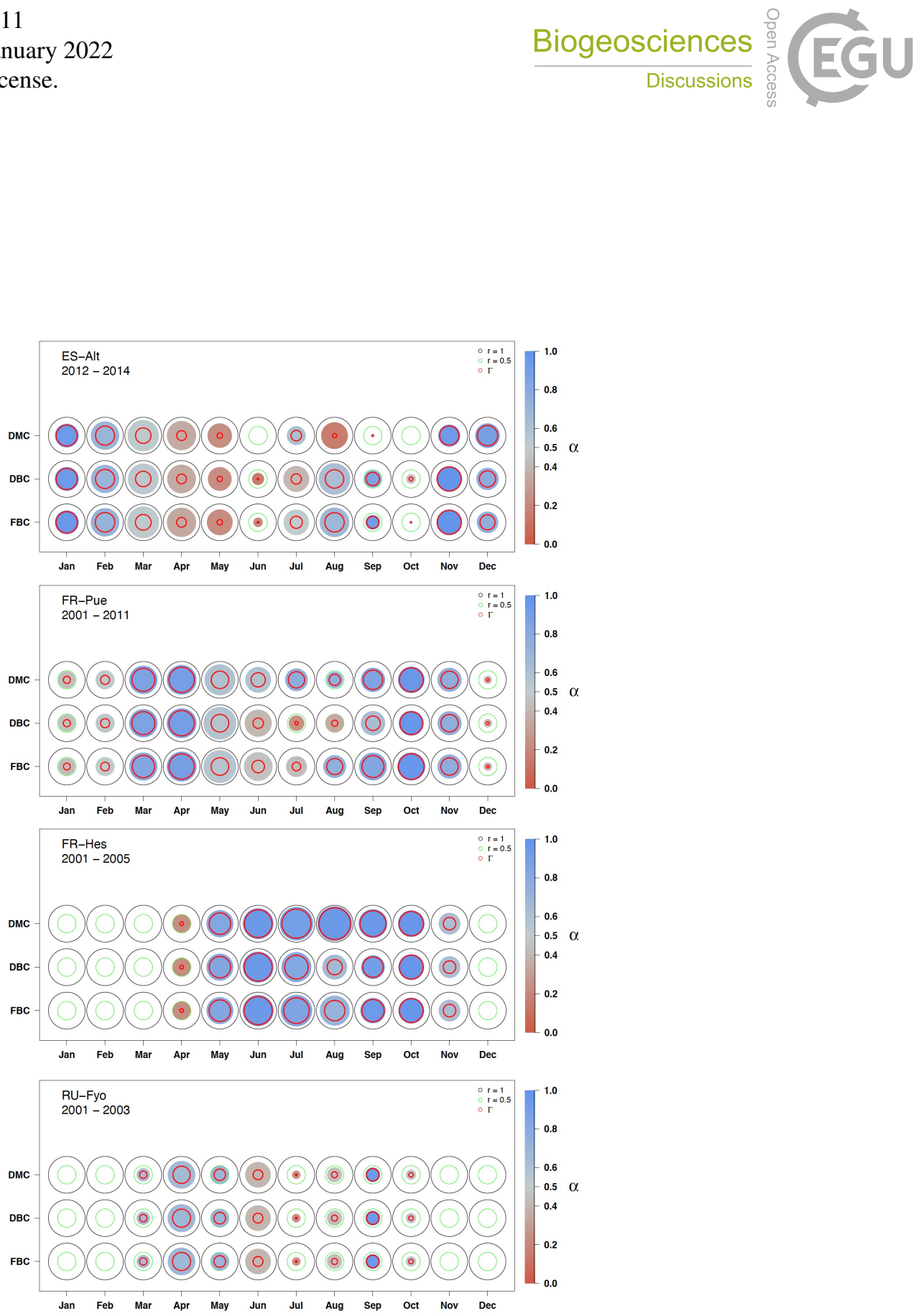

Figure 4. Multi-annual monthly variation per experimental site of the Pearson correlation coefficient $(r)$ and the index of agreement $(\Gamma)$ for the default model configuration (DMC), deeper bedrock configuration (DBC), and fractured bedrock configuration (FBC). The black and green empty circles correspond to $r$ equal to 1 and 0.5 , respectively. The size of the filled circle represents the $r$ coefficient between 0 and 1 , and when the green circle is absent the $r$ value is greater than 0.5. Negative values of $r$ are not shown in this plot. The $\alpha$ coefficient is represented by the color filling the monthly circles, where blue color represent $\alpha$ values close to 1 and dark-orange close to 0 . Finally, the red circle corresponds to $\Gamma$ index as a down-regulated $r$ coefficient proportional to the $\alpha$ coefficient (see Table A1 for the detailed list of $r$, $\alpha$, and $\Gamma$ values). 

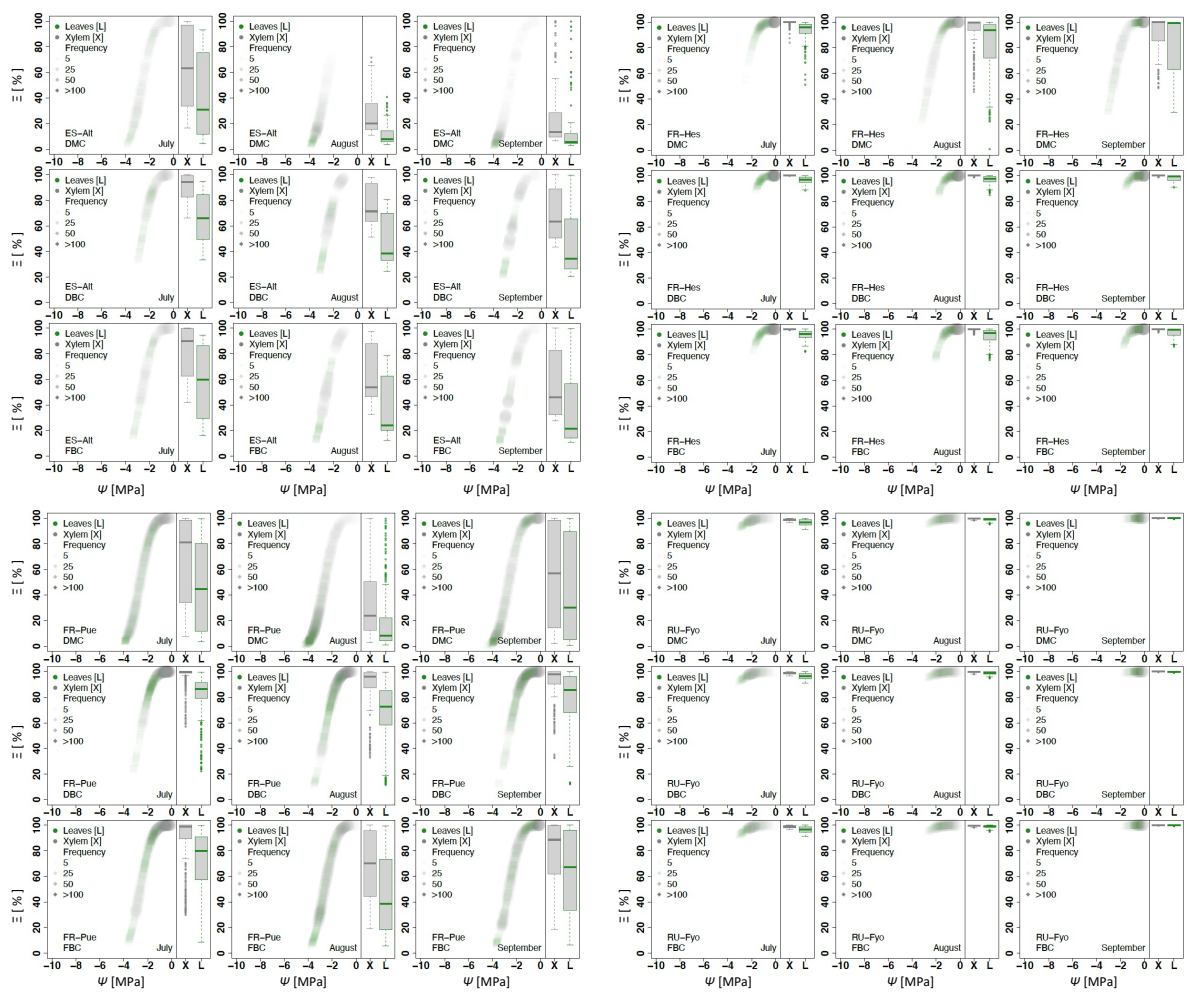

Figure 5. Plant vulnerability curves describing the hydraulic stress as percentage of conductivity $(\Xi)$ experienced by the modeled vegetation per experimental site during the drier months (July, August, and September). Each plot describes the hydraulic stress experienced by stem xylem (X) and sunny leaves xylem (L). 
Table A1. Monthly summary of the Pearson correlation coefficient (r), alpha coefficient $(\alpha)$, and symmetry index $(\Gamma)$ for the three model configurations and four experimental sites.

\begin{tabular}{|c|c|c|c|c|c|c|c|c|c|c|c|c|c|}
\hline \multirow{2}{*}{$\begin{array}{c}\text { Model } \\
\text { Configuration }\end{array}$} & \multirow{2}{*}{ Month } & \multicolumn{3}{|c|}{ ES-Alt } & \multicolumn{3}{|c|}{ FR-Pue } & \multicolumn{3}{|c|}{ FR-Hes } & \multicolumn{3}{|c|}{ RU-Fyo } \\
\hline & & $\mathrm{r}$ & $\alpha$ & $\Gamma$ & $\mathrm{r}$ & $\alpha$ & $\Gamma$ & $\mathrm{r}$ & $\alpha$ & $\Gamma$ & $\mathrm{r}$ & $\alpha$ & $\Gamma$ \\
\hline \multirow{12}{*}{ DMC } & 1 & 0.60 & 0.95 & 0.57 & 0.43 & 0.45 & 0.19 & 0.00 & 0.00 & 0.00 & 0.00 & 0.00 & 0.00 \\
\hline & 2 & 0.73 & 0.71 & 0.52 & 0.47 & 0.52 & 0.25 & 0.00 & 0.00 & 0.00 & 0.00 & 0.00 & 0.00 \\
\hline & 3 & 0.81 & 0.52 & 0.42 & 0.72 & 0.86 & 0.62 & 0.00 & 0.00 & 0.00 & 0.32 & 0.63 & 0.20 \\
\hline & 4 & 0.75 & 0.36 & 0.27 & 0.76 & 0.90 & 0.69 & 0.44 & 0.23 & 0.10 & 0.71 & 0.66 & 0.47 \\
\hline & 5 & 0.62 & 0.24 & 0.15 & 0.79 & 0.60 & 0.47 & 0.69 & 0.85 & 0.58 & 0.44 & 0.70 & 0.31 \\
\hline & 6 & -0.07 & 0.00 & 0.00 & 0.66 & 0.59 & 0.39 & 0.79 & 0.95 & 0.75 & 0.65 & 0.41 & 0.27 \\
\hline & 7 & 0.47 & 0.61 & 0.29 & 0.57 & 0.77 & 0.44 & 0.86 & 0.91 & 0.79 & 0.19 & 0.27 & 0.05 \\
\hline & 8 & 0.68 & 0.17 & 0.12 & 0.41 & 0.75 & 0.31 & 0.90 & 0.96 & 0.86 & 0.37 & 0.45 & 0.16 \\
\hline & 9 & 0.07 & 0.45 & 0.03 & 0.61 & 0.86 & 0.53 & 0.74 & 0.95 & 0.70 & 0.35 & 0.95 & 0.34 \\
\hline & 10 & -0.03 & 0.00 & 0.00 & 0.68 & 0.96 & 0.65 & 0.68 & 0.97 & 0.66 & 0.23 & 0.53 & 0.12 \\
\hline & 11 & 0.55 & 0.94 & 0.52 & 0.61 & 0.77 & 0.47 & 0.55 & 0.62 & 0.34 & 0.00 & 0.00 & 0.00 \\
\hline & 12 & 0.62 & 0.88 & 0.55 & 0.18 & 0.44 & 0.08 & 0.00 & 0.00 & 0.00 & 0.00 & 0.00 & 0.00 \\
\hline \multirow{12}{*}{ DBC } & 1 & 0.61 & 0.95 & 0.57 & 0.42 & 0.46 & 0.19 & 0.00 & 0.00 & 0.00 & 0.00 & 0.00 & 0.00 \\
\hline & 2 & 0.72 & 0.71 & 0.52 & 0.47 & 0.53 & 0.25 & 0.00 & 0.00 & 0.00 & 0.00 & 0.00 & 0.00 \\
\hline & 3 & 0.79 & 0.53 & 0.42 & 0.72 & 0.86 & 0.63 & 0.00 & 0.00 & 0.00 & 0.32 & 0.64 & 0.20 \\
\hline & 4 & 0.74 & 0.36 & 0.27 & 0.76 & 0.90 & 0.69 & 0.44 & 0.23 & 0.10 & 0.72 & 0.69 & 0.49 \\
\hline & 5 & 0.60 & 0.24 & 0.14 & 0.85 & 0.57 & 0.48 & 0.69 & 0.85 & 0.58 & 0.45 & 0.70 & 0.32 \\
\hline & 6 & 0.29 & 0.16 & 0.05 & 0.69 & 0.41 & 0.28 & 0.79 & 0.95 & 0.76 & 0.65 & 0.41 & 0.27 \\
\hline & 7 & 0.66 & 0.42 & 0.28 & 0.38 & 0.25 & 0.10 & 0.77 & 0.84 & 0.64 & 0.19 & 0.27 & 0.05 \\
\hline & 8 & 0.81 & 0.62 & 0.50 & 0.46 & 0.36 & 0.17 & 0.63 & 0.65 & 0.41 & 0.37 & 0.45 & 0.17 \\
\hline & 9 & 0.42 & 0.86 & 0.36 & 0.62 & 0.63 & 0.39 & 0.60 & 0.92 & 0.55 & 0.36 & 0.95 & 0.34 \\
\hline & 10 & 0.22 & 0.48 & 0.10 & 0.63 & 0.97 & 0.62 & 0.66 & 0.98 & 0.65 & 0.24 & 0.53 & 0.12 \\
\hline & 11 & 0.66 & 0.99 & 0.65 & 0.61 & 0.78 & 0.47 & 0.55 & 0.62 & 0.34 & 0.00 & 0.00 & 0.00 \\
\hline & 12 & 0.56 & 0.78 & 0.44 & 0.19 & 0.45 & 0.08 & 0.00 & 0.00 & 0.00 & 0.00 & 0.00 & 0.00 \\
\hline \multirow{12}{*}{ FBC } & 1 & 0.60 & 0.96 & 0.58 & 0.42 & 0.44 & 0.19 & 0.00 & 0.00 & 0.00 & 0.00 & 0.00 & 0.00 \\
\hline & 2 & 0.73 & 0.73 & 0.53 & 0.46 & 0.51 & 0.24 & 0.00 & 0.00 & 0.00 & 0.00 & 0.00 & 0.00 \\
\hline & 3 & 0.82 & 0.52 & 0.43 & 0.72 & 0.85 & 0.61 & 0.00 & 0.00 & 0.00 & 0.31 & 0.63 & 0.20 \\
\hline & 4 & 0.75 & 0.35 & 0.27 & 0.77 & 0.90 & 0.69 & 0.44 & 0.23 & 0.10 & 0.71 & 0.70 & 0.49 \\
\hline & 5 & 0.66 & 0.23 & 0.15 & 0.85 & 0.56 & 0.48 & 0.69 & 0.85 & 0.58 & 0.45 & 0.70 & 0.32 \\
\hline & 6 & 0.21 & 0.22 & 0.05 & 0.74 & 0.46 & 0.34 & 0.80 & 0.96 & 0.76 & 0.65 & 0.41 & 0.27 \\
\hline & 7 & 0.65 & 0.51 & 0.33 & 0.52 & 0.44 & 0.23 & 0.81 & 0.86 & 0.69 & 0.19 & 0.27 & 0.05 \\
\hline & 8 & 0.76 & 0.69 & 0.53 & 0.58 & 0.76 & 0.44 & 0.77 & 0.72 & 0.55 & 0.37 & 0.45 & 0.17 \\
\hline & 9 & 0.35 & 0.92 & 0.33 & 0.71 & 0.84 & 0.60 & 0.64 & 0.94 & 0.60 & 0.36 & 0.95 & 0.34 \\
\hline & 10 & 0.05 & 0.46 & 0.03 & 0.72 & 0.97 & 0.70 & 0.66 & 0.98 & 0.65 & 0.24 & 0.53 & 0.12 \\
\hline & 11 & 0.65 & 1.00 & 0.65 & 0.61 & $\mathbf{3 4}^{0.77}$ & 0.47 & 0.55 & 0.62 & 0.34 & 0.00 & 0.00 & 0.00 \\
\hline & 12 & 0.54 & 0.76 & 0.41 & 0.18 & 0.42 & 0.08 & 0.00 & 0.00 & 0.00 & 0.00 & 0.00 & 0.00 \\
\hline
\end{tabular}


https://doi.org/10.5194/bg-2021-311

Preprint. Discussion started: 28 January 2022

(c) Author(s) 2022. CC BY 4.0 License.
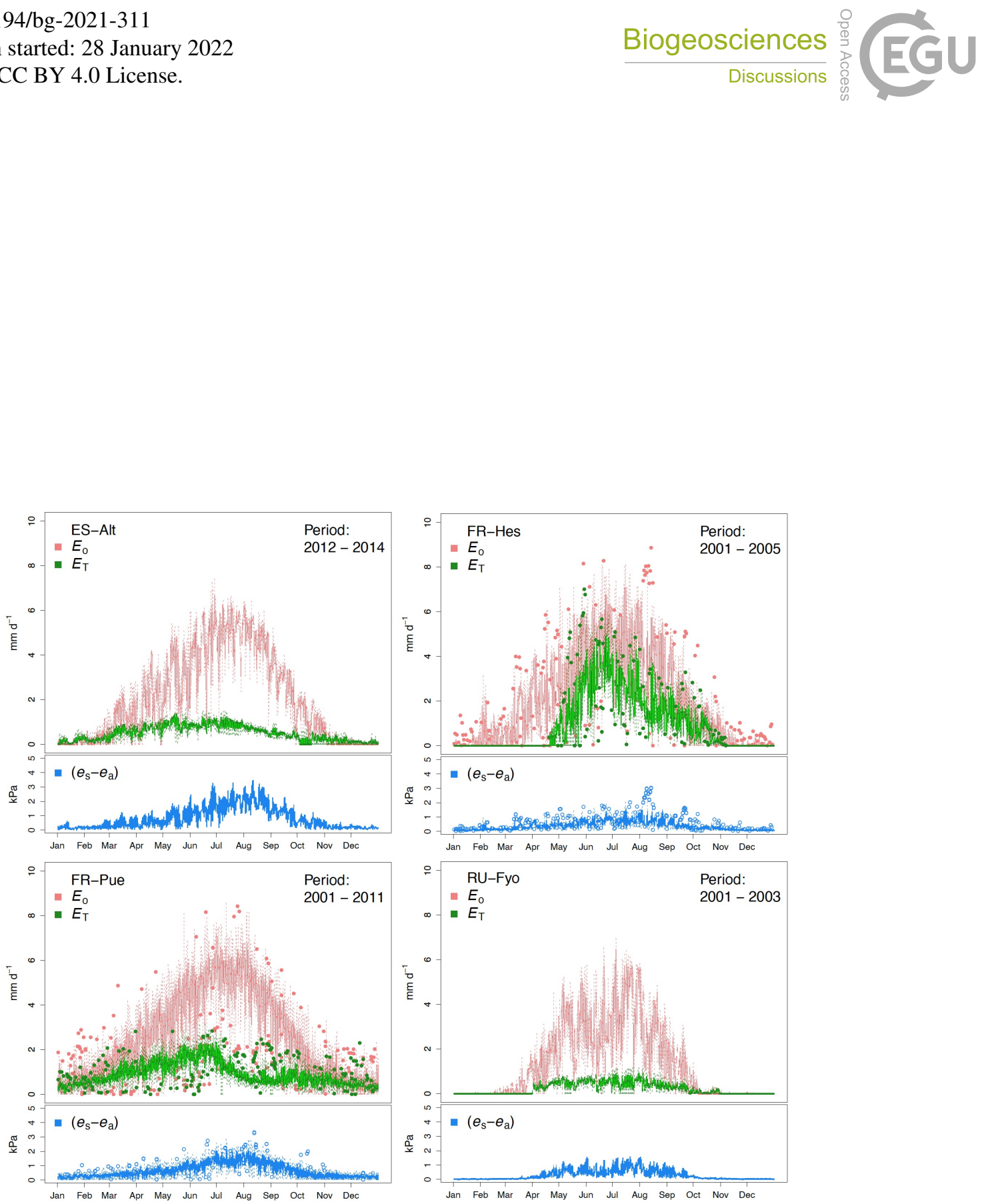

Figure A1. Multi-annual daily boxplots for potential evaporation $\left(E_{\mathrm{o}}\right)$, stand transpiration $\left(E_{\mathrm{T}}\right)$, and vapor pressure deficit $(\Lambda)$ of the selected experimental sites across Europe. 

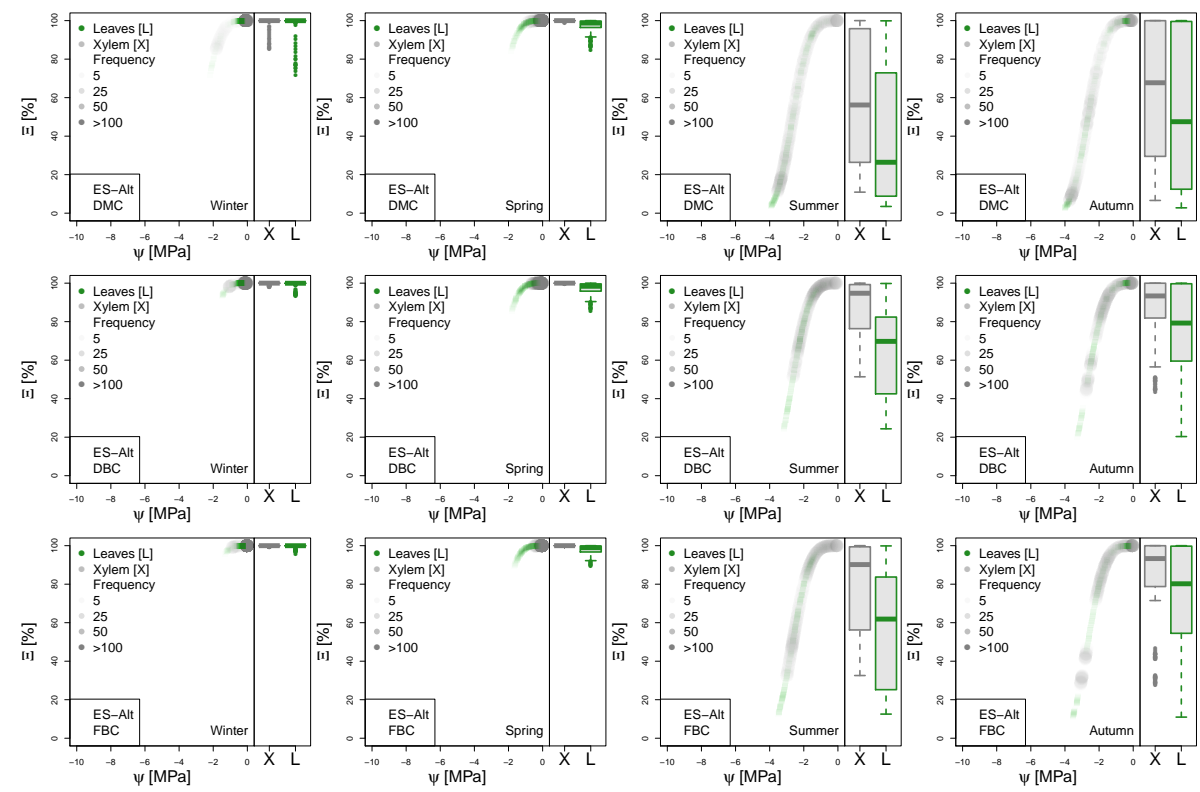

Figure A2. Seasonal variation of the plant vulnerability curves describing the hydraulic stress as percentage of conductivity ( $\Xi$ ) experienced by the modeled vegetation in ES-Alt experimental site. Each plot describes the hydraulic stress experienced by stem xylem (X) and sunny leaves xylem (L).
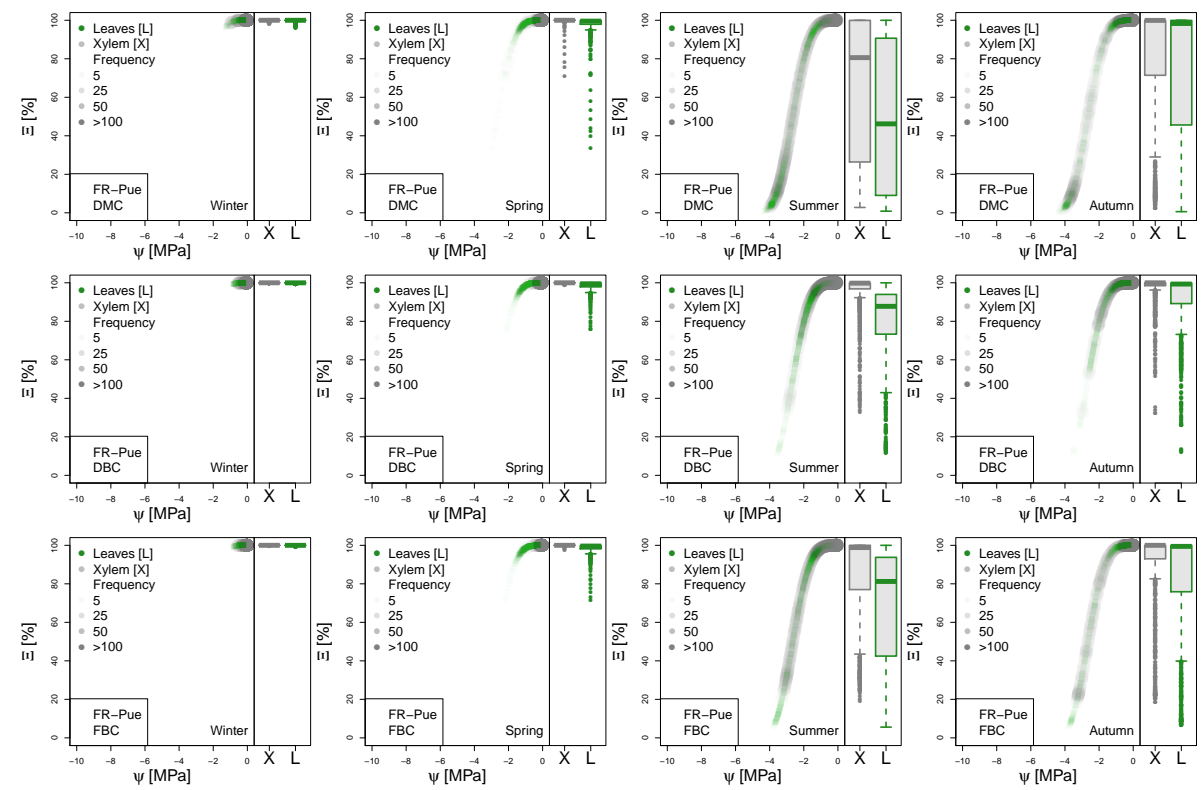

Figure A3. Seasonal variation of the plant vulnerability curves describing the hydraulic stress as percentage of conductivity ( $\Xi$ ) experienced by the modeled vegetation in FR-Pue experimental site. Each plot describes the hydraulic stress experienced by stem xylem (X) and sunny leaves xylem $(\mathrm{L})$. 

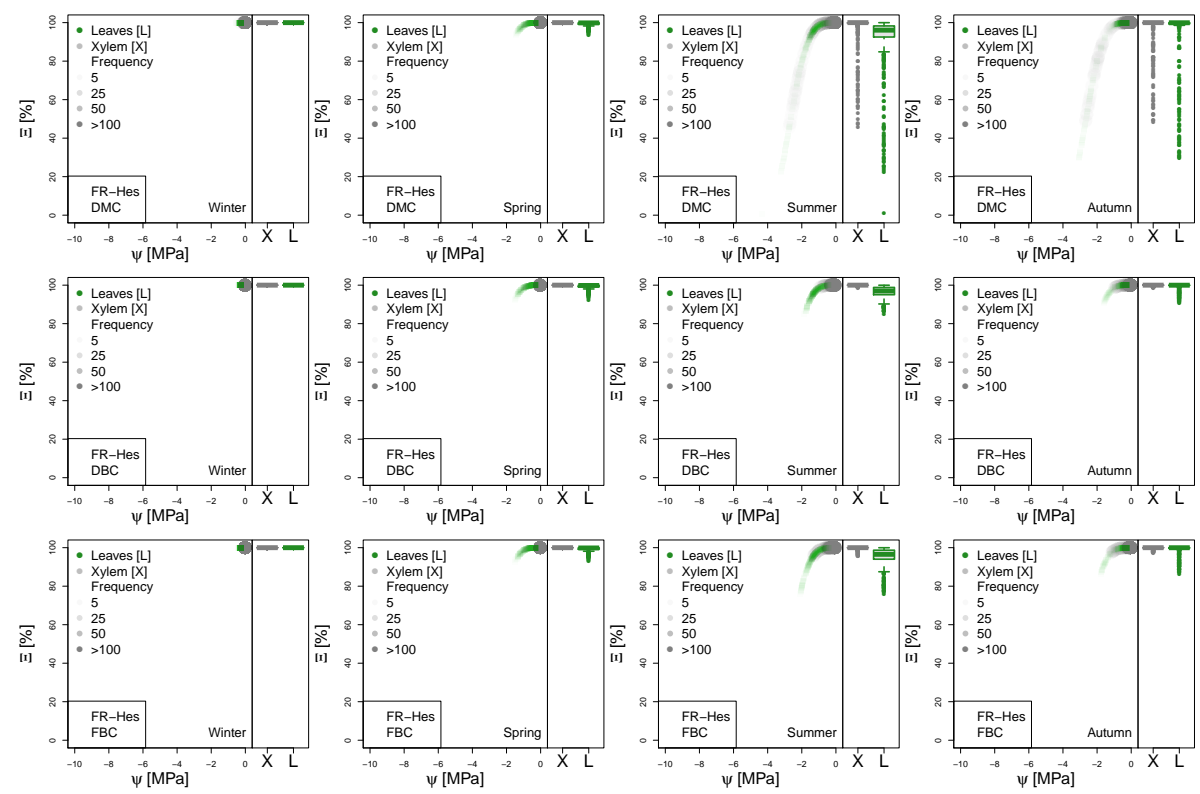

Figure A4. Seasonal variation of the plant vulnerability curves describing the hydraulic stress as percentage of conductivity $(\Xi)$ experienced by the modeled vegetation in FR-Hes experimental site. Each plot describes the hydraulic stress experienced by stem xylem (X) and sunny leaves xylem (L).
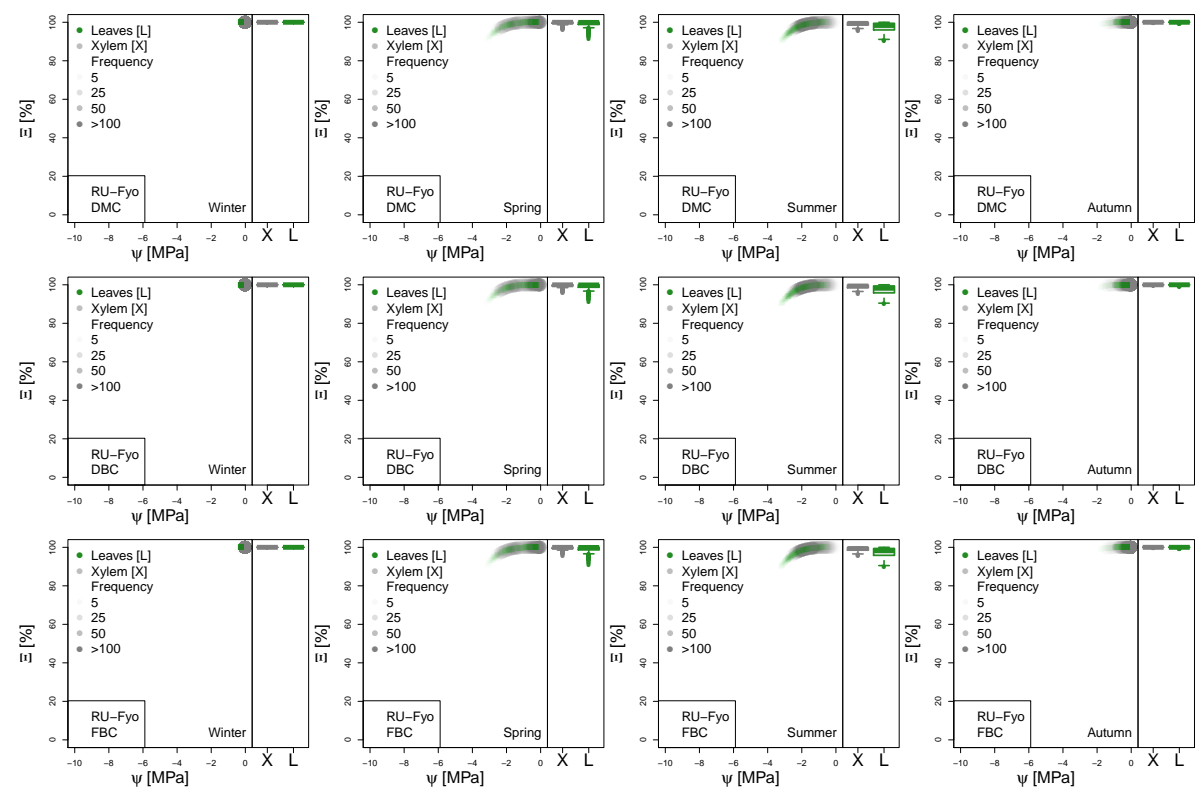

Figure A5. Seasonal variation of the plant vulnerability curves describing the hydraulic stress as percentage of conductivity $(\Xi)$ experienced by the modeled vegetation in RU-Fyo experimental site. Each plot describes the hydraulic stress experienced by stem xylem (X) and sunny leaves xylem (L). 